\title{
“The Infurnal Thing": Autonomy and Ability in Narratives of Disabling, Self-acting, and Weaponized Prostheses
}

Though not a prosthesis in quite the same way as an artificial leg, the mechanical trousers of Nick Park's 1993 Academy Award-winning animated short Wallace and Gromit: The Wrong Trousers provides a useful entry point for thinking about themes of autonomy and ability in relation to replacement body parts. ${ }^{1}$ In Park's imaginative universe, Wallace purchases a pair of ex-NASA mechanical trousers for his companion dog Gromit as a birthday present. Not quite a direct physical replacement for Wallace's legs but certainly a functional supplement, unfortunately for Park's eponymous characters, these trousers do not behave as they should. Riffing off the popular sci-fi trope of the machine-gone-bad- $\grave{a}$ la the Terminator franchise - the controls for the trousers end up in the wrong hands (or wings) as the device is used to perform a bank robbery by the criminal mastermind penguin, Feathers McGraw. Most distressingly for Wallace, this feat is performed while he is asleep wearing the so-called techno-trousers. This story is clearly more fun than serious, but what cannot be denied is that part of the representational force of the piece stems from the way that it playfully engages with genuine human anxieties, namely those related to a body part holding the body whole to ransomwith technology usurping the human as master, and with technological improvements rendering some more able than others. As I argue here, these very themes were hallmarks of representations of self-acting and weaponized prostheses over a century before Park's popular animation.

(C) The Author(s) 2022

R. Sweet, Prosthetic Body Parts in Nineteenth-Century Literature and Culture, Palgrave Studies in Nineteenth-Century Writing and Culture, https://doi.org/10.1007/978-3-030-78589-5_3 
The focus of this chapter is on autonomy as a framing concept in nineteenth- and early twentieth-century representations of prosthetic body parts. By placing imaginaries of devices such as artificial legs, arms, eyes, and teeth in context with contextual factors that brought understandings of human and machine agency under the spotlight, I maintain that several prosthesis narratives problematized the contemporary hegemony of physical wholeness (explored in the previous chapter) by imaging powerful non-normative and non-human alternatives-human-machine splices that are enhanced by prosthetic technologies. These parts challenge the autonomy of the host, the body rendered whole by prosthesis. For this reason, my discussion unveils a paradox: stories that focus upon prostheticsdevices underpinned by an ableist medical-model understanding of bodily difference, which are used to normalize deviant bodies-often challenge the very philosophy that has brought about the use of prosthetic body parts. These tales mobilize bodily alternatives that compete with hegemonic norms. The following analysis both develops and contrasts Erin O'Connor's argument that "at the body-machine interface lies a 'prosthetic territory,' a frontier of potential resistance whose liberatory effects derive, paradoxically, from a strategic complicity with and dependence on machines." I show how prosthetics were imagined as both liberating and restricting, and how, in many cases, the human-machine splice that the use of these devices engendered was imagined as a threat to the organic body. In each case, the autonomy of prosthesis-using subjects (seeming cyborgs in certain instances) or the powerful prosthetic device that they use, or are used by, challenged the preference for physical wholeness by imagining the possible results that such social pressures could bring about: life forms more potent than normal human subjects.

In terms of its engagement with prostheses, devices sometimes imagined as kinds of machines in the literature of the nineteenth century, my analysis provides further evidence for Tamara Ketabgian's observations regarding the animacy of machines in the Victorian imagination:

$[\mathrm{M}]$ achines were not simply soulless, lifeless, predictable, and unidimensional; not simply opposed to organic feeling and vitality; and not simply reductive material objects-if objects are ever so. They lead such a rich figurative life, yielding a broad literary array of habits, feelings, communities, and subjectivities. As science and technology studies have shown, these engines served as coordinated dynamic networks, with systems of complex interdependence that formatively shaped physiological and thermodynamic models of life. ${ }^{3}$ 
I explore the perceived autonomy of the mechanical prosthetic body part, particularly in a section where I analyse the self-acting prostheses that appear in Frances Parker, Countess of Morley's The Flying Burgermaster (1832), the popular song "Cork Leg” (published by John Ashton in 1888 but in circulation for many years before), and J. Stuart Blackton's short film The Thieving Hand (1908). ${ }^{4}$ In these instances, the representation of the prosthetic body part foreshadows Jacques Derrida's warning about the "supplement" (for him, writing), a signifier that he calls a dangerous since it "claims to be presence and the sign of the thing itself." As Derrida contends: "It is the addition of a technique, a sort of artificial and artful ruse to make speech present when it is actually absent." ${ }^{5}$ The supplement is dangerous as it "threatens to subvert and supplant the whole by questioning the whole's structural integrity." This same dynamic can be seen in nineteenth-century prosthesis narratives. In the literary representations in question, users are often either rendered less human by using primitive forms of prosthesis or made slaves to the will of hyper-sophisticated devices.

\section{Human-Machine Minds and Bodies}

The anxieties relating to prosthesis and autonomy conflate various nineteenth-century cultural misgivings surrounding human-machine and mind-body relationships, machine autonomy, and ontology. As numerous critics have observed, a significant amount of nineteenth-century cultural attention to these topics revealed alarm about a loss of human agency in light of the materialist "disenchantment" of life and the unrelenting forward march of technology. ${ }^{7}$ The emergence of self-acting machines, such as the Jacquard loom and Charles Babbage's Difference Engine, encouraged contemporaries to reconsider the subject/object binary. The use of newly fashioned self-feedback loops to produce automatic processes made machines appear more lifelike, while, thanks to a host of influential evolutionary and materialist theories, humans increasingly came to be understood as almost machine-like- “conscious automata" as psycho-physiologist Thomas Henry Huxley would argue in $1874 .{ }^{8}$

Many were optimistic about the rise of empirical science and about the productive potential of new, self-acting technologies. The Scottish professor Andrew Ure, a figure that many consider to be the chief apologist of nineteenth-century machinery, was a notable example. In The Philosophy of Manufacture (1835), he raved about a self-acting mule (a machine 
invented in the late eighteenth century to effect more efficient yarn spinning), which he claimed was "a creation destined to restore order among the industrious classes, and to confirm Great Britain in the empire of art." Babbage was similarly sanguine about the utilitarian benefits of machinery. In An Essay on the General Principles Which Regulate the Application of Machinery to Manufactures and the Mechanical Arts (1827), he talked highly of the reparative capacity of man's fusion with technology: “a less general use of tools for human hands, is to assist the labour of those who are deprived by nature, or by accident, of some of their limbs.... These triumphs of skill and ingenuity deserve a double portion of our admiration when applied to mitigate the severity of natural or accidental misfortune." "For technophiles such as Babbage, industrial machines offered an alternative solution to the crisis of physical loss. By mobilizing a framework of human-machine splicing, Babbage's techno-optimistic view was linked to but different from the popular view that concealing prostheses provided cures for perceived physical losses. Concealing physical differences to look able would become less necessary if industrial machines could be operated by non-normative bodies.

In addition to the voices of technophiles, such as Ure and Babbage, who encouraged the rise of intelligent machines, theories also emerged that sought to redefine the human body in mechanical terms. The growth of the new science of thermodynamics, the branch of physics that dealt with the relationship between heat and other types of energy, led to a radical reconceptualization of the active human as fundamentally an engine. Jenny Uglow suggests that these theories harked back to Julien Offray de La Mettrie's L'Homme Machine (1747), which (partly provoked by René Descartes's definition of animals as "automata") attempted to "restate the problem of the mind as physical, not meta-physical - to define man as a mechanical entity in which perception, emotion, understanding, foresight and thought were produced by organic causes." Ure and Babbage talked about intelligent machines, as Anson Rabinbach explains, scientists also linked the understanding of humans as machines to a drive for progress: "If the working body was a motor, some scientists reasoned, it might even be possible to eliminate the stubborn resistance to perpetual work that distinguished the human body from a machine."12 Such a technological forward march was also promised by contemporary psycho-physiologists, the forerunners of modern psychology, who from the 1870s onwards encouraged a reconsideration of the mind-body relationship. They suggested that, like the body, the mind is subject to causes 
and actions instigated by changes in force and matter. As several critics have observed, this materialist philosophy proved controversial because it questioned the existence of both human free will and divine agency, suggesting instead that human action is determined by evolutionary, environmental, and physical causes. ${ }^{13}$ While proponents of psycho-physiology, such as Herbert Spencer, Alexander Bain, Henry Maudsley, William Kingdon Clifford, and Huxley, recognized the possible ethical and religious implications of undermining the existence of human free will (they often posed dualistic theories that sought to encourage a materialist understanding of the mind while simultaneously encouraging readers to respond ethically to the determining forces of nature), many remained resistant to this philosophical position, which seemed to render humans equivalent to machines despite each theorist's careful treatment of the concept of free will.

The most extreme resistance to "the rise of the machine" occurred earlier in the century, during what has been named the Luddite movement. While the actions of the Luddites responded less to the philosophical dehumanizing of humanity than it did to the physical implications and social injustices caused by technological innovation, agency was nonetheless a major concern to these revolutionaries. To these radicals, technology was robbing human workers of their freedom since machines were beginning to take the place of people in the industrial workplace. As a response to the perceived crisis of unemployment effected by the rise of selfregulating machines, such as the Jacquard loom, working-class men-who claimed to be led by the mythical King Ludd-broke into factories and destroyed machinery. At least one factory owner was killed in these violent protests. This technological resistance lasted roughly from 1812 to 1817 , but the legacy of technophobia endured for many years afterwards. Even today, technophobes are sometimes described as "Luddites."

After the Luddite movement subsided in 1817, a cultural resistance to the rise of science and technology remained prominent. One year after the Luddite movement ended, Mary Shelley published Frankenstein, or the Modern Prometheus (1818), a story that is widely held to deliver "a powerful anti-science diatribe that still reverberates as a quintessential parable of the dangers unleashed by technological creation and irresponsible scientists." 14 In later cultural representations of human interaction with new technologies, including the steam engine, a more complex relationship was often displayed. As Nicholas Daly reminds us, a great number of plays premiered in the 1860s, for example, Dion Boucicault's After Dark 
(1868), which relied on a "cultural imaginary in which the impact of the machine, or industrial modernity more generally, on the human is a source of trepidation, or even terror, though also of fascination." 15 Along similar lines, Charles Dickens was another prominent cultural figure who displayed an acute awareness of the potential negative effects of new technology. He was "exhilarated by speed and novelty" of the railway, but "remain[ed] sceptical about the social consequences of applied technology on this scale." ${ }^{\prime 6}$ Dickens's mixed feelings towards the railway are exemplified in both Dombey and Son (1846-1848) and the famous ghost story "The Signal Man" (1866) ${ }^{17}$ Cultural apprehensions about the forward march of technology were again brought to the attention of the reading public by a series of science-fiction novels written by $\mathrm{H}$. G. Wells in the 1890s, including The Time Machine (1895), The Island of Dr. Morean (1896), The Invisible Man (1897), and When the Sleeper Wakes (1899)..$^{18}$ Each of these novels depicts the potentially dystopic results of scientific experimentation or technological development gone wrong. The nervousness in many of these cultural portrayals of technology centres on a fear relating to diminishing human agency. The worry for many was that the increasing intimacy between human and machine, which saw a rebalancing of the user-technology hierarchy, could lead to the technological part usurping the human user, rendering him or her either redundant or mechanical. Enmeshed in debates surrounding the rise of technology and an increasing understanding of the human in materialist terms, what follows explores fictional responses to the physical splicing of human and thing. The rise of the machine, as manifest in the prosthetic body part, embodied a threat to the hegemony of the physically and organically whole human.

To assess the variety of fictional responses to concepts of prosthesis and autonomy, this chapter is split into three thematic sections, which each include analyses of works from across the period that this book explores. The first section examines representations of devices that either enable or inhibit user agency. Here I focus closely on two writings that simultaneously reveal and dismiss the extent to which technological apparatuses can provide physical autonomy to their users: Edgar Allan Poe's “The Man That Was Used Up" (1839) and Herman Melville's Moby-Dick (1851). ${ }^{19}$ As I show, despite presenting entirely contrasting prostheses in terms of sophistication, these sources in varying ways problematized the demand for prostheses that was encouraged by a society that privileged wholeness. Prostheses are depicted interchangeably as dehumanizing and ineffective. 
A specific example of a character (Captain Boomer) who uses a nonnormative prosthesis to maintain authority in Moby-Dick provides a segue to the next section, which explores prosthetic technologies imagined to transgressively enable their users. The dominance of physical wholeness is challenged more directly in the stories covered, which present users who find violent means with which to assert themselves. This section explores in detail the enduring motif of prosthesis as weapon, providing close readings of a variety of writings including Thomas Hood's Miss Kilmansegg and Her Precious Leg (1840-1841) and Arthur Conan Doyle's The Sign of Four (1890). ${ }^{20}$ Thinking in further depth about threatening machine agencies, the final section explores the self-acting prostheses of Parker's The Flying Burgermaster and Blackton's The Thieving Hand, among others. Collectively, my analyses consider the extent to which prostheses and their users were imagined in ways that defied hegemonic organic bodily norms.

\section{Productive Prostheses}

In Erin O'Connor's influential study of nineteenth-century amputation and lower-limb prostheses, she argues that " $[\mathrm{m}]$ echanizing the amputee in order to naturalize him, the discourse of prosthesis redistributes the qualities of personhood across an economy of body and machine." ${ }^{21}$ In an optimistic manner, she demonstrates how artificial limb makers asserted the abilities of their devices to "rehabilitate recalcitrant bodies," enabling male amputees to return to work, thereby restoring the masculinity jeopardized by losing a limb and returning him to a state of autonomy. ${ }^{22}$ Despite invoking literary works including Charles Dickens's novels Our Mutual Friend (1864-1865) and Pickwick Papers (1836-1837), and Anthony Trollope's He Knew He Was Right (1869), O'Connor provides limited evidence that contemporary literary depictions of prosthetics supported the utilitarian ideal espoused elsewhere. ${ }^{23}$ Imaginative engagements with the topic complicate the view that O'Connor addresses.

In support of the utilitarian-essentialist view of prosthetics that O'Connor identifies, a small number of fictional tales supported the enabling potential of contemporary prosthetics. For example, an 1872 sketch for Kind Words titled "A Romance of War" tells the story of a maimed war veteran thought dead, who thanks to the use of an artificial leg and patent arm becomes a successful grocer. ${ }^{24} \mathrm{He}$ is also able to remarry his wife, who thought he had been killed in action and had married another 
man. In the 1874 All the Year Round short story "Peg-Legged Bob," a maimed navvy is bought a well-made artificial leg, which, though not good enough a substitute to enable him to return to manual work, allows him to become a contractor. ${ }^{25}$ These technophilic depictions of artificial limbs are no doubt linked to the air of optimism and achievement surrounding prostheses in the wake of the American Civil War (1861-1865), a conflict that many historians hold accountable for major developments in artificial limbs. ${ }^{26}$ In 1864, the famous American poet and physician Oliver Wendell Holmes boasted that America "has bestowed upon you and all the world an anodyne which enables you to cut arms and legs off without hurting the patient; and when his leg is off, she has given you a true artist's limb for your cripple to walk upon, instead of the peg on which he has stumped from the days of Guy de Chauliac to those of M. Nelaton."27

Concerning ocular prostheses, in M. E. Francis's 1900 short story "A Rustic Argus" a man with one eye is convinced by the sister of his lover to use a prosthesis. ${ }^{28} \mathrm{He}$ heeds her advice and wears a prosthesis with profound effect. He even claims that it enhances his eyesight. Though clearly hyperbolic, this representation followed major developments made in artificial eyes. In the 1890s, the Snellen, or "reform" eye as it was sometimes known, was developed by the Müller family in Wiesbaden in response to ophthalmologist Hermann Snellen's call for more suitable prostheses for enucleated eye sockets to be produced. These devices of a double shell design better filled the cavity left after enucleation, removing the sunken appearance that previous designs effected. ${ }^{29}$ In 1900, Pache and Son of Birmingham were makers to the principal hospitals in Britain and could provide the "reform eye." 30

Simultaneously aligning with the optimistic view of prosthetics outlined in the stories above while also exposing angst regarding the potentially dehumanizing effect of a human-machine splice, Edgar Allan Poe's 1839 story "The Man That Was Used Up" is a literary source that O'Connor gives close attention to. ${ }^{31}$ In Poe's narrative, which is framed as a kind of detective story, the narrator tries to find out the secret behind Brevet Brigadier General John A. B. C. Smith, a figure who is at once mysterious and striking in appearance. As is revealed in a grotesque dressing scene, the veteran of the Bugaboo and Kickapoo campaign is a maimed man almost entirely made up of prosthetics. Due to his impressive appearance when fully assembled, Smith is shown to use devices that not only conceal his bodily losses but appear to improve upon nature. The narrator 
is awestruck by Smith's appearance during their first encounter: "His head of hair would have done honor to a Brutus"; his teeth were "the most entirely even, and the most brilliantly white of all conceivable teeth"; his eyes were "of a deep hazel, exceedingly large and lustrous"; his bust was "unquestionably the finest" that the narrator ever saw; his arms were "altogether were admirably modelled"; and his lower limbs were the "ne plus ultra of good legs." 32 Even Smith's apparent stiffness, an early sign of his artificial composition, is viewed positively by the narrator:

There was a primness, not to say a stiffness, in his carriage-a degree of measured, and, if I may so express it, of rectangular precision, attending his every movement, which, observed in a more diminutive figure, would have had the least little savor in the world, of affectation, pomposity or constraint, but which noticed in a gentlemen of his undoubted dimensions, was readily placed to the account of reserve, hauteur - of a commendable sense, in short, of what is due to the dignity of colossal proportion. ${ }^{33}$

Smith's devices are notable for their mimetic capacities but are even more impressive in terms of the way that they provide the severely injured subject both a degree of physical autonomy and an impression of grandeur.

However, as the title of the story suggests, despite the impressiveness of Poe's prostheses, the narrative is less troubled with the imagined ameliorative capacities of prosthetics than it is with the effects that a humanmachine splice has ontologically. When a man is more machine than human, how does this affect his personhood? Who is in control, him or his devices? It is significant that Smith is described as "the man that was used up" (emphasis original), rather than "the man that was made up." 34 James Berkley notes that in the nineteenth century "used up" could mean "not only 'to expend' or 'to exhaust' (its normal meaning today) but also 'to debunk' or 'to critique." "35 The title thus describes both a man who is physically reduced and a man whose very personhood is put into question; its passive verb construction implies that the man is not a user but an object of use by someone (or something) else. Smith has been "used up" by a life of military duty and, in some ways, perhaps, by his increasing reliance on prostheses. Drawing our attention to the extent to which Poe's autonomy is compromised by his reliance on technology, O'Connor argues that "The Man That Was Used Up" celebrates "the constitutive powers of prosthetics as a means of taking them to task." "Centring on a man who has more artificial parts than organic ones," O'Connor suggests, 
"Poe's story critiques the logic of prosthesis by turning it inside out." 36 Like Mr. Pinto from William Makepeace Thackeray's 1862 sensationfiction parody "The Notch on the Ax," another character who is heavily supplemented with prostheses whose representation raises questions about who or what is in control, it is unclear in the case of Smith what is part and what is whole. ${ }^{37}$

Though Poe's story is by no means a realistic portrayal of nineteenthcentury prostheses, precisely because the devices presented are far more sophisticated than those that were available even at the end of the century, the story does anticipate the boom in prosthesis manufacture and distribution that occurred during and after the American Civil War. Highlighting the correlation between conflict and prosthesis development, Katherine Ott reveals: "The Civil War in the United States and the Napoleonic Wars in Europe initiated the first large-scale attention to prosthetics and their design and use." ${ }^{38}$ Applying this technological narrative of progress to "The Man That Was Used Up," Vanessa Warne notes that "Poe's story anticipates [the developments in the design, manufacture, and marketing of prosthetic body parts], accurately envisioning the commercialism, technological character, and normalizing goals of post-bellum America's response to disabled war veterans." 39 The narrator's horror at witnessing Smith being literally reassembled by his slave, Pompey, at the end of the narrative, is comically contrasted with Smith's recommendations of prosthesis makers. Smith's championing of certain brands of prosthesis, including Thomas's cork legs, Bishop's artificial arms, Pettitt's shoulders, Ducrow's bosoms, Bonfanti's palate, De L'Orme's wigs, Parmly's dentures, and Dr. Williams's sight-enabling artificial eyes, brings to mind a popular feature of nineteenth-century prosthesis treatises, publications that promised potential clients that prosthetics could enable the same degree of autonomy afforded to the nondisabled in wider society.

A familiar component of the pamphlets, books, and other advertisements published by prosthetists on both sides of the Atlantic in this period was the testimonials section, or "letters pages" as it was sometimes labelled. In this popularly deployed section, the testimonials of named or anonymous users, medical professionals, or technology experts were printed together. Occasionally these were divided into subsections based on the age, gender, profession, and disability of the writer. In all cases, these letters would laud the capabilities of the products produced by the advertised prosthetist, and occasionally they would disparage the devices of other makers. In Douglas Bly's Description of a New, Curious, and Important 
Invention (1859), a report by A. P. Sigourney, Chairman of New York State Fair Committee, compared the maker's artificial legs to rival prosthetist Benjamin Franklin Palmer's devices: "We are unanimous in the opinion that the Leg presented by DR. BLY is the best, and that it possesses advantages over the 'Palmer Leg' very desirable to the user, and creditable to its maker." 40 In his privileging of the devices of certain makers over those made by others (i.e. he recommends Thomas's cork legs but suggests that Bishop makes superior artificial arms), Smith pre-empts the kinds of debates that would occur within the rhetorical literature published by prosthesis makers from the 1850s onwards. As Kevin J. Hayes observes: "each of General John A.B.C. Smith's prosthetics is identified with a specific brand name; put together, they virtually turn him into a walking advertisement." ${ }^{\prime 1}$

While Poe's narrative, on the one hand, sanguinely imagines a future in which the most physically damaged bodies can be recuperated and made whole again by prostheses, it is typical, on the other hand, of nineteenthcentury prosthesis narratives in that it does not fully support prosthesis in either conceptual or practical terms. "The Man That Was Used Up" makes fun of a prostheticized physical aesthetic while challenging the contemporary preference for organic physical wholeness in a couple of ways. In practical terms, Poe's narrative critiques prostheses in two ways. First, despite their impressiveness at first glance, Smith's adornments produce a curiously rigid aesthetic, which invites curiosity: though the narrator is initially wowed by Smith's appearance, he nevertheless notices Smith's rigidity, thereby stimulating an investigation. The second practical aspect of Smith's prosthesis use, which is similarly comically explored, concerns the user's assembly process. Because these devices are not fully integrated with the subject and thus need to be removed at certain times of the daybefore bed, for instance-there are periods when the prosthesis user is rendered almost entirely reliant on others. Smith's rudeness towards his slave, who helps him to attach his various prostheses, reveals a frustration at such a compromise. Though presented in a disablist grotesque fashion, which makes a spectacle of the disabled body, Poe's narrative nonetheless problematizes prostheses as complete solutions to the perceived crisis of physical loss. In conceptual terms, Poe's critique of physical wholeness is also twofold. On the one hand, the hegemony of organic completeness is challenged by a prostheticized figure, someone who is neither fully organic nor physically whole, whose appearance when fully constructed is more impressive than physically normative subjects. On the other hand, the very 
drive to construct an appearance of integrity is rendered absurd as we witness a subject go from a state equivalent to the titular "human bundle" of Ernest George Henham's 1897 short story, to a shape that is imposing and impressive though decidedly mechanical. ${ }^{42}$ The falseness engendered by prostheses is taken to a hyperbolic extreme. The following analysis exposes other ways in which the notion of prostheticizing the body was challenged and the hegemony of wholeness distorted in nineteenth- and early twentieth-century prosthesis narratives.

\section{Disabling Devices}

While Smith, to a degree, is remarkably enabled by his use of prosthetics, several other representations from the period focus on the inabilities of these devices to grant users autonomy. A few years before Poe's story was published, a tale titled "Wooden Legs" (1833) appeared in the Court Magazine and Belle Assemblée that mocked the efficacy of sophisticated artificial legs. At the time, such devices were made at an increasing rate in Britain and America, following the success of James Pott's famous Anglesey leg, which I return to below. ${ }^{43}$ In the story, a Napoleonic War veteran mistakenly puts on a friend's expensive patented artificial leg after a heavy night of drinking. The combination of his drunken state with a device that was earlier shown to be tricky to use results in repeated falls, creating a cruelly comical scene. ${ }^{44}$ Similarly, Hood's popular satirical poem Miss Kilmansegg and Her Precious Leg mocks a pompous amputee who demands an artificial leg made of solid gold. Unsurprisingly, her device is shown to be cumbersome, heavy, and impractical. While the artificial leg in Hood's poem is undoubtedly, as Warne suggests, a symbol through which the mismanagement of money is explored, the poem also exposes contemporary disquiet about the weight of artificial legs and was used in contemporary prosthesis advertising as an example of how limb prostheses should not be constructed. ${ }^{45}$

Once we turn to the second half of the nineteenth century, a period heralded by popular historian Guy Woodforde as "the era of false teeth for the masses" due to technological developments that made the manufacture of these technologies cheaper, we encounter numerous stories and jokes that mocked the propensity of false teeth to malfunction. ${ }^{46}$ Published in All the Year Round, "Too Hard upon My Aunt" (1863), for instance, tells the story of the narrator's aunt who suffers a mysterious "illness" after eating boiled-beef in the company of a love interest. ${ }^{47}$ As is revealed, she is 
a false teeth user. Her dentures broke during the meal, hence her feigned illness. Hyperbolizing the inability of wigs to stay attached to their users' heads, the 1895 Illustrated Chips cartoon “The Wig Wouldn't Work Like the Natural" shows how representations of ineffective prostheses continued late into the century. ${ }^{48}$ The cartoon depicts a comic artist prone to pulling his hair, who ends up using a wig and pulling off with a "wild, mad tug," much to his embarrassment. ${ }^{49}$ In each of these stories, the autonomy of a subject is impacted by using an artificial body part. The very employment of these contraptions, which promised to enable users to meet emerging standards of normalcy, was therefore critiqued. These imaginaries present prosthetic devices that create rather than cure physical differences.

A famous example of a prosthetic body part that is disabling rather than enabling is Captain Ahab's ivory leg in Melville's Moby-Dick. This epic narrative questions the notion that prostheses provide a medical fix or cure for physical loss, instead recognizing the virtues of building a more inclusive and accessible environment. In this respect, the novel projects a fairly forward-thinking way of responding to physical difference. Though, in other regards - for instance, in the way that Ahab's abhorrent monomaniacal traits are equated with and represented physically by his disabilitythe novel is typically disablist in its treatment of physical difference. ${ }^{50} \mathrm{On}$ the positive side, Ahab is granted a degree of physical autonomy in what would normally be a particularly inaccessible workspace, thanks to numerous adaptations made to his ship, the Pequod. These developments compensate for the limited autonomy enabled by the amputee's ivory prosthesis, a device that further injures him, "all but pierc[ing] his groin," late in the novel..$^{51}$ Counteracting the limitations of Ahab's ivory leg, the Pequod's adaptations serve as a kind of extension of the captain's prosthetic device. Ahab's leg literally attaches to the deck of the vessel, simultaneously enabling him while also revealing the limitations of his ivory leg.

The Pequod is both an add-on to Ahab's prosthesis and a further physical manifestation of the captain's monomaniacal obsession-the leg made from the ivory of the same species that severed his leg being a related example. Ahab's peg directly joins him to his vessel. As the sailor Ishmael, who tells the story, reveals: "Upon each side of the Pequod's quarterdeck, and pretty close to the mizen shrouds, there was an auger hole, bored about half an inch or so, into the plank. His bone leg steadied in that hole; one arm elevated, and holding by a shroud." ${ }^{2}$ Here, then, the Pequod is literally pegged to Ahab-or vice versa. As we learn, like Ahab's 
leg, the destiny of the ship, and its crew, is firmly attached to the captain's obsessive agenda: to "dismember [his] dismemberer," the white sperm whale Moby Dick. ${ }^{53}$ As David T. Mitchell and Sharon L. Snyder have observed: "Each of the innovations and inventions" used by Ahab on the Pequod, including not just the auger hole and shroud but also the "iron banister" that he grips, the winch and saddle that carries him up to the ship's rigging, and the "spare boats, and spare lines and harpoons, and spare everythings" that Ishmael exhaustively describes, are "paraded not as evidence of Ahab's resourcefulness, but as proof of the extent to which he will go to fulfill his 'singular' quest." 54 The ship is also marked by Ahab's obsessiveness. The deck is all over dented "like geological stones, with the peculiar mark of [Ahab's] walk ... the foot-prints of his one unsleeping, ever-pacing thought." ${ }^{55}$ Here, then, the leg is a direct extension of Ahab's will. Like Ahab, the Pequod is also said to exhibit signs of physical abnormality: "She was a ship of the old school, rather small if anything; with an old fashioned claw-footed look about her." 56 Also resembling the captain, the vessel is adorned with the teeth of sperm whales, hence why it is described as the "ivory Pequod." 57 Emphasizing the affinities between Ahab and his ship, at the end of the narrative it is even said that "the rushing Pequod ... seemed the material counterpart of her monomaniac commander's soul." 58

As we can see from these convergences between Ahab and his ship, everything on the Pequod is unified in its purpose-in this case to enable the captain to complete his obsessive mission. Like Brevet Brigadier General John A. B. C. Smith's prosthetic parts, which are united in their purpose (to create an impression of the veteran's robustness and dauntlessness of character), here the ship's modifications work together to enable the disabled user. As we see in Poe's narrative, Melville's novel invites attention to the limitations of prostheses while condoning a prejudiced view of disabled subjects: Poe projects Smith as an object of grotesque spectacle while Melville endorses a view that links physical disability to moral corruption. However, in terms of attitude to the dominance of physical integrity, the representation of Ahab resists the impulse to prostheticize to conceal. Instead, Ahab uses alternative-though also prosthetic-methods to enable himself physically.

A second amputee character in Melville's novel, one who also makes manifest a dubious link between physical loss and violent intentions, is Captain Boomer, another victim of Moby Dick. Like Ahab, Boomer uses a prosthetic device. Though what distinguishes Boomer is that his 
prosthesis is specially designed to act as a weapon. In addition to reinforcing a problematic cultural association of physical difference with violence, Boomer's depiction also ironically challenges the hegemony of physical wholeness but in a remarkably different way. Here a prosthesis user is provided with a device that extends his abilities in a focused direction. As fighting cocks were sometimes adorned with metal spurs, Boomer is provided a prosthesis that makes him better prepared for combat. He therefore challenges physical hierarchies that placed the disabled below the nondisabled. Despite the Captain's objections, it is quite apparent that violence was his intention when he ordered the device. As the captain's doctor describes it: "he ordered the carpenter to make it; he had that clubhammer there put to the end, to knock some one's brains out with, I suppose, as he tried mine once. He flies into diabolical passions sometimes."59 Here, we learn that the captain's prosthesis is designed specially to fit not just his body but also his violent temperament. The prosthesis, then, is an extension of the captain's volatile character as much as it is a replacement for his severed arm. In a similar but not identical way to Ahab, Boomer is revealed to be mentally unhinged, once more problematically suggesting that psychological trauma is an inevitable consequence of physical loss.

But unlike Ahab, Boomer is not interested in seeking vengeance. He admits that he has seen Moby Dick twice since his arm was lost. When asked by Ahab if he could not "fasten," in other words, capture the whale, Boomer retorts, "Didn't want to try to: ain't one limb enough? What should I do without this other arm? And I'm thinking Moby Dick doesn't bite so much as he swallows." Boomer later contemplates that " $[\mathrm{t}]$ here would be great glory in killing him, I know that; and there is a ship-load of precious sperm in him, but, hark ye, he's best left alone." ${ }^{60}$ It is therefore clear that unlike Ahab, Boomer's motives lie in glory and financial reward rather than revenge. Regardless of his reluctance to pursue "the white whale" and his differing motives to Ahab, Boomer's club-shaped prosthesis is nonetheless represented as a physical manifestation of his own mental instability, one that ironically empowers the amputee over his nondisabled crew.

As we learn, Boomer went against the advice of his ship's doctor, Bunger, by having such a crudely shaped device fitted. "I had no hand in shipping that ivory arm there," Bunger states, "that thing is against all rule." ${ }_{11}$ The rules that Bunger speaks of perhaps refer to the intended concealing capacities of prosthetic devices. This commitment to the mimesis of the organic body part is underscored by George E. Marks in his 
1888 treatise on the artificial limbs produced by his family's firm A. A. Marks. Marks describes the social expectations that surrounded prosthesis design in the mid-century: "The demand for artificial limbs was noticeably increasing; the field was growing larger; the cry for something more durable and more approximate to nature came from every quarter." 22 Despite these directives, some prosthesis users fashioned devices designed for violent purposes. For instance, British artificial limb and orthopaedic appliance maker Henry Heather Bigg made an artificial hand furnished with a dagger for a furs collector working for the Hudson Bay Company. The device was produced upon request as the amputee wished to be able to defend himself against wild animals. ${ }^{63}$ In Melville's story, Bunger is clearly not a fan of Boomer's prosthesis, in part because of the captain's violent past-Bunger suggests to Ahab that the captain gave him "bowl-like cavity in his skull." ${ }^{44}$ While Boomer strongly refutes this claim, his very denial conjures an image of violence, containing a thinly veiled threat: "Oh, you solemn rogue, you-you Bunger! was there ever such another Bunger in the watery world? Bunger, when you die, you ought to die in pickle, you dog, you should be preserved to future ages, you rascal." ${ }^{\prime 65}$ Boomer clearly attempts to sound jocular, but his over-emphatic tone and use of morbid imagery suggests an immovable presence of violence within his imagination.

Boomer's prosthesis challenges the hegemony of the normal body in two ways: first, the club-shaped prosthesis defies social and medical expectations that prosthetic devices should look and function like real human body parts; second, in the form of his club arm, Boomer is provided a violent and immediate means with which to assert himself, which in one respect provides him with a physical advantage over his nondisabled peers. Boomer can be read to anticipate violently equipped amputees of the modern era, such as RoboCop, who has a pistol concealed in his robotic leg; Merle Dixon from the popular AMC series The Walking Dead (2010), who, like Bigg's patient, has a prosthetic bayonet arm. The same might be said of Cherry Darling from Robert Rodriguez's Planet Terror (2007), who has an assault rifle (complete with grenade launcher) in the place of an artificial leg. ${ }^{66}$ As the next section shows, in addition to imagining prostheses specifically designed for confrontation, quotidian prosthetics, such as wooden legs, were represented as devices that could be used in threatening ways. 


\section{Prostheses as Weapons}

Since the "turn to users" that was inspired by the work of Ruth Schwartz Cowan, Science and Technology Studies (STS) scholars have shifted their attention from investigating the impact of inventors and designers to focus on the user. ${ }^{67}$ Most recently, these scholars have focused on "how users consume, modify, domesticate, design, reconfigure, and resist technologies." ${ }^{68}$ While we cannot be certain that fictional portrayals of prosthesis directly informed the modifications made to artificial body parts by contemporary prosthetists, we can be sure that these portrayals drew from and informed social and cultural views of prosthesis design and use. By exploring the non-normative uses of prosthetic devices in fictional accounts, I demonstrate how prosthetic body parts were imagined as devices that were not necessarily capable of restoring the appearance and function of a lost body part but were able to provide their users with deadly and closeto-hand weapons. The logic of prostheticizing the body to recomplete it was therefore complicated by literary characters who provided a powerful challenge to the hegemonic normal body.

In literary works, prosthesis use often has little to do with restoring bodily wholeness. In various examples from nineteenth- and early twentieth-century literature and film, we see prostheses fulfil various unusual and often comical purposes far removed from the ideal of prostheses as cures for physical loss. For instance, the Satirist published a story in 1845 that encouraged women to use wigs for making lockets to send to lovers so that they could entertain multiple partners without going bald. ${ }^{69}$ In "The Lame Landlord's Story," a wooden leg is made into a cupboard that stocks sweetmeats, a pipe, and tobacco. ${ }^{70}$ By comparison, in Mark Twain's Roughing It (1872) a vagabond sneakily uses a cork leg to obtain brandy. After an "awkward express empoyé" drops a one-hundred-pound brick on the man's foot, the victim falls to the ground clutching his apparently damaged extremity. When a "sympathizing crowd" come to the man's aid and attempt to remove his boot, he screams louder, calling for "Brandy! for Heaven's sake brandy!"71 Having rejected the offer of having a doctor called, the vagabond asks for more brandy and is given two bottles in addition to the half pint he had already consumed. As it turns out, the man is not hurt since the brick falls upon his cork leg. The man merely pretended to be in pain to obtain liquor. Taking an entirely different direction, an 1895 cartoon for Illustrated Chips illustrated how well adapted peg legs were for turning fields. ${ }^{72}$ Though not all engaging with disability 
as we understand it today but rather (in the case of baldness) perceived bodily non-normativity, writings such as these provide intriguing instances of what Tobin Siebers calls "disability masquerade": "an alternative method of managing social stigma through disguise, one relying not on the imitation of a dominant social role but on the assumption of an identity marked as stigmatized, marginal, or inferior." 73 The imagined prosthesis users depicted in the Sativist narrative, "The Lame Landlord's Story," Twain's sketch, and the Illustrated Chips cartoon do not attempt to pass as normal. Instead, they perform, utilize, and, in certain cases, exaggerate physical difference to achieve success in ableist environments.

In other cultural sources, alternatives to normativity were imagined in the form of prostheses that provide effective defensive capabilities. For example, in a 1904 article for $J u d y$, a contributor comically extols the multitudinous tasks that a set of false teeth could perform:

False teeth can be used for letter clips, clothes pegs, and several other useful purposes. They can be fitted with a spring and placed on the floor to act as a trap for burglars. The burglar generally creeps about noiselessly in his stockinged feet, and when he incautiously places his foot upon one of these traps, which have been left in the room or upon the stairs for that purpose, he lets out a yell which awakens the inmates and gives the and him the alarm. ${ }^{74}$

In a similarly comical fashion, Arthur Cooper's 1903 short film Blind Man's Bluff depicts a beggar with an apparent vision impairment and amputated leg who strikes a passer-by with his wooden leg after he is given a bogus coin. ${ }^{75}$ The film not only reimagines the association between disability, prosthesis use, begging, and imposture (a topic that I discuss at length in Chap. 4), but also reveals a common trope in the representation of human prosthesis in the long nineteenth century: the portrayal of the prosthetic weapon.

Prosthetic legs used as improvised bludgeons appeared in numerous stories in the nineteenth and early twentieth centuries, including in Hood's Miss Kilmansegg and Her Precious Leg, Henry Clay Lewis's “The Indefatigable Bear Hunter" (1850), R. M. Ballantyne's Why I Did Not Become a Sailor (1864), D. B. McKean's "A Wig and a Wooden Leg” (1886), and Arthur Conan Doyle's The Sign of Four. ${ }^{76}$ In 1899, the Nottinghamshire Guardian printed a short report on a wooden-leg user who had been charged for assaulting a railway officer with his wooden 
leg. ${ }^{77}$ Similarly, in 1904 the Daily Mail reported another real-life account of such an incident in which an individual named John Feenan used his limb as a "shillelagh" when intoxicated. ${ }^{78}$ In the rest of this section, I examine three of these sources-Hood's poem, Lewis's short story, and Doyle's novel-to show how this trope encompassed a variety of complex attitudes to contemporary standards of prosthetics, the human-technology relationship more broadly, and the extent to which the power of the normate could be challenged by the violent potential of lower-limb prosthetics.

To begin with Hood's poem, a writing well known throughout the nineteenth century, we see a violent representation of a golden leg that, though absurdly humorous, became a popular paradigm for how false limbs should not look or function. ${ }^{79}$ In Hood's poem, Miss Kilmansegg is brutally murdered by her husband, an avaricious Italian count who has accumulated considerable gambling debts. The count clubs his wife to death with the very item that he wishes to possess: the countess's golden leg. While the leg displayed in Hood's poem is by no means a realistic portrayal of a nineteenth-century prosthetic device, its representation as a weapon nonetheless reveals some of the apprehensions that surrounded prosthesis design in this period. One reason that Miss Kilmansegg's leg makes such an excellent club is because of its weightiness. The countess's prosthesis is made of "Gold-solid gold throughout" and is said to be "As solid as man could make it." ${ }^{80}$ Considering the density of gold, it is not surprising that the device is so heavy. The hefty and cumbersome nature of Miss Kilmansegg's prosthesis is revealed by the descriptions of her noisy gait:

When slow, and heavy, and dead as a dump,

They heard a foot begin to stump,

Thump! lump!

Lump! thump! ${ }^{81}$

The noisiness of the device becomes a nuisance to Miss Kilmansegg's murderous husband, who tries to convince his wife to exchange her golden leg for a wooden one, in part because of "the unbearable thumping" that the device makes - the other reason being so that he can sell the golden leg to pay off his gambling debts. ${ }^{82}$ Here, the efficacy of the artificial body part is questioned, since the device clearly does not enable its user to pass as someone with two natural lower limbs; its obnoxiousness both visually and audibly brings its presence to the fore. Miss Kilmansegg's leg does 
precisely the opposite of what good artificial legs were supposed to do: it invites rather than evades attention. The device thus works in opposition to the social demands for silent artificial limbs that do not call attention to themselves. Her leg is not only unhelpfully heavy but also so ostentatious as to attract the unwanted attention of a suitor with murderous designs.

Due to its weight and clumsy design, Miss Kilmansegg's leg is shown to be more effective as a weapon than as a functional replacement for a leg. The cumbersome weightiness of the leg, which is not articulated, compromises the mobility of the user, but makes for an excellent weapon. In several instances the device is displayed as an impractical appendage. While the stiffness of Miss Kilmansegg's prosthesis makes her leg look like that of "a Figurantê" at "Her Fancy Ball," practical activities, such as walking and climbing over obstacles, are made difficult by her choice of prosthesis. ${ }^{83}$ As the speaker notes, "She hated walking in any shape,/And a country stile was an awkward scrape." ${ }^{84}$ In contrast to these difficulties, the leg is shown to be an excellent bludgeon by her barbarous husband. The prosthesis makes short work of the hapless Miss Kilmansegg:
'Twas the Golden Leg! — she knew its gleam!
And up she started, and tried to scream,-
But ev'n in the moment she started-
Down came the limb with a frightful smash,
And, lost in the universal flash
That her eyeballs made at so mortal a crash,
The Spark, called Vital, departed! ${ }^{85}$

This scene makes explicit the power of the artificial part. In the violent collision between flesh and gold, only the latter survives, revealing the impressionable, delicate nature of the former and the hard, uncompromising form of the latter. The prosthesis is rendered other to body by its material properties, which so drastically contrast with that of the body. The way in which the prosthetic smashes skull, haemorrhages brain, and ultimately kills so effectively-in one blow-makes manifest the discrepancy between the natural and the artificial. Here, then, the prosthetic part, a device designed to make the body whole again, does quite the opposite as it not only further damages its intended user but is used to kill her. In this way, the impulse to prostheticize, an inclination buttressed by a culturally enforced desire to present oneself as physically whole, is challenged in two ways: on the one hand, the false part is shown to be dangerously 
incongruous to the natural body; on the other hand, exaggerating real-life unease about the prohibitive price of top-of-the-range artificial limbs, the false part is valued more greatly than human life.

Articulating the prosthesis as a weapon in a more sanguine manner, Lewis's "The Indefatigable Bear Hunter" effectually unites the user and device. Following the loss of his leg in a hunting accident, the bear hunter who is described in the title, Mik-hoo-tah, continues to hunt against the advice of his doctor. After a hunt goes wrong and he is forced into a fist fight with a bear, Mik uses his wooden leg to beat his furry foe to death. Though brutal, such a use of a wooden leg brings about a more intimate relationship between hunter and prosthesis. The relationship between user and device does not begin on strong footing, however. Prior to and even during his fight with the bear, Mik is revealed to be rather discontented with his wooden leg. Mik did not want to lose his actual leg in the first place (despite its mangled condition): as the doctor reveals, Mik "opposed [amputation] vehemently." 86 Similarly, after the doctor convinces Mik that amputation is the only fit course of action, and the life-saving procedure is promptly performed, the hunter falls into a state of depression, losing a considerable amount of weight - the doctor remarks "I have never seen anyone fall off so fast." ${ }^{\prime 87}$ When the doctor asks Mik if he has contracted consumption, the hunter reveals that his physiological state is tied to his disability and, possibly, to his use of a rudimentary prosthetic: "Doc, it's grief, poor sorrur, sorrur, Doc! When I looks at what I is now and what I used to be!"88 In the heat of the battle, Mik curses his peg leg several times for getting stuck in the uncompromising swamp terrain, referring to it as an "infurnal" and " $\mathrm{d}[$ amne $] \mathrm{d}$ thing." 89 Despite his reservations, after he successfully slays the bear using his prosthesis, Mik celebrates his success. "I hollered," Mik reveals, "I had whipped a bar in a fair hand to hand fight-me, a old, sickly, one-legged bar hunter!" ${ }^{90}$ It is significant that Mik considers the bout with the bear "a fair hand to hand fight," entirely forgetting the fact that he used a weapon (albeit an unusual one) to bludgeon his opponent. He clubs the bear so hard with his wooden leg that its "flesh giv in to the soft impresshuns of that leg," before finishing off his unconscious adversary with a second, more conventional weapon: a knife. ${ }^{91}$ By considering the encounter a fist fight, Mik unconsciously reveals his acceptance of the prosthetic device as a part of his anatomy.

Revealing to the doctor his triumph over the bear, Mik also ironically praises "the mederkal perfeshun for having invented sich a weepun!" 92 To Mik the prosthetic limb is noticeably more effective as a weapon than it is 
a substitute for an organic limb. This line of thought is not surprising when one compares Mik's locomotive immobility with the devastating efficacy of his prosthesis as a club. Mik explains that he had "only one leg that cood run!" suggesting that his only option with the bear was to fight rather than flee. ${ }^{93}$ Mik's frustration at being rendered static by his leg's inability to function on soft terrain is mitigated by the bear hunter's very use of the prosthetic as a bludgeon. Though we learn relatively little about the design of Mik's prosthesis - other than the fact that it is crafted by the Swamp Doctor narrator himself-we can safely assume that, since the device was not made by a prosthesis specialist, it is of a rudimentary design. This prosthetic most likely resembles a peg rather than an artificial leg. The narrator at no point claims to be an expert in prosthesis manufacture. He elsewhere reveals the extent to which doctors in his position are forced to improvise when he describes the equipment used to amputate Mik's leg. After listing implements including "[a] couple of bowie knives, one ingeniously hacked and filed into a saw, a tourniquet made of a belt and piece of stick, a gun screw converted for the time into a tenaculum, and some buckskin slips for ligatures," the Swamp Doctor provides the following message to more affluent practitioners: "The city physician may smile at this recital, but I assure him many a more difficult operation than the amputation of a leg has been performed by his humble brother in the swamp with far more simple means than those I have mentioned." 94

Like the amputation itself, which, as shown by Mik's subsequent bout of illness and weight loss, is by no means a complete success, the doctor's prosthesis is certainly not perfect. As it is of a rudimentary, peg-like design, it is not entirely surprising that the prosthesis functions better as a club than as a false leg. Unlike real legs, peg legs were predominantly unarticulated, rigid, and occasionally rather weighty thus making them ideal instruments for bludgeoning. That the false leg is better used as a weapon than as a practical and ameliorative replacement for a real leg underlines the otherness of primitive forms of prosthesis. Furthermore, the fact that the device is used as a club, an extension of the arm that, in the words of Harvey Green, "multiplies the force of the hand and arm because the far end travels much faster than the end in one's hands," signifies that it ironically enhances the capabilities of its user. ${ }^{95}$ The false leg is effective to Mik as a tool rather than as a body part. The device enables the user but only in a way that compensates for its inability to grant full physical functionality. Though hardly an archetype for a new technologized bodily model, 
Mik's non-normative bodily image and functionality challenged the hegemony of physical wholeness as it imagines a prosthesis user that resists passing. Mik instead uses his artificial body part in a manner that arguably makes him more capable (in certain violent ways) than a nondisabled person. The wooden leg, though not an effective prosthesis in the traditional sense, is shown to be a physical extension of the character's violent persona-recalling Captain Boomer from Moby-Dick. Together, Mik and his wooden leg embody a robust non-normative alternative to physical wholeness. Lewis's tale imagines a scenario in which by losing a leg one can gain a deadly weapon.

With the aptness of peg legs for violent ends, it is perhaps unsurprising that Doyle's prosthesis-using villain Jonathan Small, in The Sign of Four, is revealed to have used his prosthesis in an act of cold-blooded murder. While Small's false leg, like Mik's, is shown to be fundamentally flawed in terms of its use on soft ground-while attempting to escape from the authorities, he is caught by Sherlock Holmes after his peg bores itself into a muddy riverbank - the efficacy of a wooden leg as a weapon is once again lauded. After his capture at the hands of Holmes, the nondisabled "calculating machine," Small reveals his history, including an incident in which he battered a prison guard to death using his wooden leg. ${ }^{96}$ Like Mik, Small used his prosthesis as a kind of improvised club. Small explains to Holmes how he managed to escape from a prison on a tropical island. As Small recalls, having made plans with his comrade Tonga to be collected by boat from a nearby wharf, the only guard that stood between Small and freedom happened to be, in the words of the amputee man himself, "a vile Pathan who had never missed a chance of insulting and injuring me."97 Revealing his bloodthirsty nature, Small exacted his revenge:

I looked about for a stone to beat out his brains with, but none could I see.

Then a queer thought came into my head and showed me where I could lay my hand on a weapon. I sat down in the darkness and unstrapped my wooden leg. With three long hops I was on him. He put his carbine to his shoulder, but I struck him full, and knocked the whole front of his skull in. You can see the split in the wood now where I hit him. ${ }^{98}$

While the guard in question put up somewhat less of a fight than the enraged bear that Mik bludgeons, there remain similarities between the two disabled characters' uses of false limbs. First, in both cases the wooden 
leg is used in an act of improvisation, when more conventional weapons could not be sought. In Mik's case, he only reverts to using his leg as a club after the bear survives being shot, having the stock of Mik's rifle broken over its head, and being hit by the severed barrel; after all alternative options are exhausted, and the barrel of his rifle is knocked out of his hand, Mik turns to his wooden leg. Similarly, Small uses his wooden leg as a weapon only after he cannot find a suitable stone to pummel the guard with. The fact that the prosthesis is a last resort is ironic since it is undoubtedly the weapon that is closest to hand. In both cases, the efficacy of the prosthetic leg as a weapon cannot be doubted. Indeed, in both accounts, those on the wrong end of the prosthesis are despatched with relative ease, revealing the discrepancy between flesh and wood. While both narratives show that the rudimentary design of peg legs make them poor replacements for human legs—as both wooden-leg users get quite literally "stuck in the mud"- - here their hardness and inhumanity are drawn attention to. In this sense, then, both stories provide a subtle critique of primitive lower-limb prostheses, suggesting that they are better adapted to being used as weapons than as functional substitutes for missing legs. In this sense, these stories challenge contemporary demands for amputees to prostheticize by suggesting that peg legs, the lower-limb prostheses most affordable to the masses, could barely enable users to walk let alone pass as normal.

Despite this seemingly important message, the treatment of prosthesis as weapon is rather comical in both stories. In The Sign of Four, for instance, the police officer that eventually arrests Small makes this joke: "I'll take particular care that you don't club me with your wooden leg, whatever you may have done to the gentleman at the Andaman Isles." 99 Lewis's story meanwhile is laden with absurd details about rural life in the American South designed to elicit laughter from metropolitan audiences. But both tales make a serious point about the inefficacy of nineteenthcentury peg legs. These representations mobilize an alternative model of physical incompleteness: the users of artificial limbs are shown to be conspicuously deficient in locomotive capacities but enhanced when it comes to hand-to-hand (or rather leg-to-head) combat. Wooden-leg users are imagined to use their non-normative bodies effectively in non-conventional ways, challenging the physical hierarchies that placed the conspicuously incomplete below those who were deemed physically whole.

The use of prosthesis as weapon, however, also reveals an ableist disquietude regarding the disabled user. To use terminology borrowed from 
Madeleine Akrich, while murderers such as Small do not correspond with the "projected user" envisaged by the makers of prosthetic limbs, amputees and disabled people in general were subject to a number of stereotypes that often equated physical disaggregation with moral deficiency. ${ }^{100}$ Discussing the portrayal of disability in Western literature and film in general, Jenny Morris identifies that "beauty — and goodness - are defined by the absence of disability ... ugliness - and evil—are defined by its presence." ${ }^{101}$ In more nuanced work on the subject, Mitchell and Snyder have suggested:

The disabled body became an important means of artistic characterization, for it allowed authors to visually privilege something amiss or "tragically flawed" in the very biology of an embodied character. While disability had historically provided an outward sign of disfavor or monstrous inhumanity, the nineteenth century shifted the emphasis to a more earthbound principle of moral decrepitude and individual malfunction. ${ }^{102}$

Along similar lines, underscoring once again the long-held belief in the link between physical trauma and a propensity to violence, David A. Gerber notes that "societies have long been haunted by fears of the violent potential of veterans with unpredictable mental states." 103 As James Marten identifies, statistics arising from the American Civil War supported these worries: "In Lancaster County, Pennsylvania, a postwar increase in crime was fuelled largely by returning veterans, who committed nearly half of all offenses, especially 'moral' and property crimes." 104 In this sense, then, one can consider Small's missing leg as a physical signifier for his villainy and violence. The loss of a limb is not too different from an "anomaly," an "abnormal" facial feature that Cesare Lombroso suggested indicated that an individual "may display profound moral maladjustment." 105 While Small very much embodies the villainous stereotypes that surrounded disabled people, Mik is not too far from this typecast either. Like Small, Mik displays an evident inclination towards violence and, if anything, is more bloodthirsty in his "indefatigable" hunting of bears than the opportunistic villain of Doyle's story. In one sense, then, Mik and Small are rendered further abnormal by their uses of prostheses as weapons. Their cyborgian adoption of prosthetic technologies provides a comically treated but nonetheless culturally loaded challenge to contemporary bodily hierarchies. 


\section{Self-acting Prostheses}

Alongside the prosthesis-as-weapon imaginary, a related trope, which conceptualized the dangerous potential of false body parts while mustering a challenge to preferences for organic wholeness, is the portrayal of the selfacting prosthetic. Mobilizations of this trope ask the following question: What happens if prosthetics, devices imagined to be more physically robust than human flesh, become so sophisticated that they begin to possess agency of their own? Parker's narrative poem The Flying Burgermaster and the popular song "Cork Leg" tell almost the same basic story about a wealthy member of the European upper classes who loses a leg and purchases a false limb, which turns out to be so sophisticated that it literally walks its user to death. While a comical reviewer writing in Judy in 1904 joked about the jovial possibilities of self-acting prosthetics, jesting that "Smiling teeth may be purchased by the set without extra charge for the smile," here automatous devices were presented in a more threatening manner. ${ }^{106}$ Besides Parker's poem and "Cork Leg," a number of other fictional stories imagined unruly prosthetics, including All the Year Round's “Bolderoe's Widow” (1876), Allsopp Æsop's “The Wooden Leg and the Ungrateful Pensioner" (1878), Every Week's “A Wooden Leg That Knows a Thing or Two" (1895), Frank Crane's "Willie Westinghouse Edison Smith" cartoons "Willie Westinghouse Invents an Automatic Arm" (1904) and "Willie's 'Handshaker' Gets Papa into Trouble” (1907), and J. Stuart Blackton's The Thieving Hand. ${ }^{107}$ These stories either present self-acting devices that malfunction - that is, prostheses that refuse to stop at the command of the user-or display intelligent devices, ones whose desires are often at odds with their users. By focusing on Parker's poem and Blackton's film, I argue that these representations draw from contemporary anxieties relating to technological developments while presenting powerful non-human and physically incomplete subjects, ones that challenge the normate.

In Parker's poem, following the amputation of his leg, the comically named protagonist, Wodenblock, is delighted to learn of the also aptly named "great mechanic" Turningvort's artificial leg. The "cork leg" is "of such perfection;/So firm, yet steady, that it stood,/Walked, danced, and ran, like flesh and blood."108 Wodenblock is attracted to Turningvort's prosthesis because of the device's ability to mimic not only the appearance but also the function of a real leg. He thus has no qualms about ordering the prosthesis. He pays a rather large sum to acquire the device-enough 
to pay for Turningvort's daughter's marriage dower. Initially, the protagonist's new prosthesis appears to be a success. The device is so well-formed that it is said to make the Burgermaster's other leg look feeble in comparison:

Once more a biped-Wodenblock

Stands firm and steady as a rock-

Complacently the limb he eyed,

And thought the old one by its side

Look'd thin and shabby-truth to tell,

It boasted not the graceful swell

Or taper ancle of the other,

But seemed a starving younger brother. ${ }^{109}$

Though the device is clearly impressively made, the fact that the artificial limb makes his other look incongruous implies that there is a discrepancy between the device and user. Unlike the contemporary representations of peg legs, here the user's body is insufficient compared to the prosthesis rather than vice versa. The false part is shown to be an improvement on nature. There are hints that the desire for prostheses that can enable one to pass has gone too far. The false part fails to conform to the demands for physical wholeness, inverting preferences for the organic.

Perhaps out of fear from encountering the kind of difficulties that Mik and Small experience while using their prostheses on rough terrain, Wodenblock initially avoids "crooked lanes and allies" on his first walk using the artificial leg. His worries are soon allayed:

With smiling looks, and air confiding,

Down broad strait streets triumphant gliding.

The leg displayed no turn for kicking,

A little whirl-a gentle ticking;

Was all the fault he could descry,

And that he thought would soon pass by. ${ }^{110}$

However, this confidence in the limb is short-lived. When he attempts to turn around to greet a friend, his leg is shown to possess a different agenda:

He wheeled around without reflection,

Quite in the opposite direction 
To that which he had just pursued;

When-as with magic power endued

A sudden jerk, a whirling thrill-

The leg no more obeys his will;

In haste, he had omitted learning

Which spring to touch in case of turning;

And prest on one of wondrous force,

To impel him on his forward course.

The act was scarce performed, when lo!

Swift as the arrow from the bow,

He felt himself compelled to fly[.] $]^{111}$

Here, the Burgermaster's leg is not only self-acting but also entirely rebellious. Unwilling to heed the commands of its wearer, the leg takes on a direction of its own at a frightful pace-one not dissimilar to Wallace's "wrong trousers." The leg proceeds to drag its user through the woods and "O'er dykes, morasses, rivers, floods," leaving the wearer "Exhausted, trembling, gasping, fainting." 112 The unrelenting march of the artificial leg eventually results in Wodenblock's death. Even after the user's death, the leg compels his skeleton to keep marching. By rendering the ghost of the amputee a "slave to all eternity," the poem presents a technological refashioning of the Christian "Wandering Jew" legend, which tells the story of a Jewish man, who as a consequence of rejecting Jesus is condemned to walk the world homeless until the second coming. ${ }^{113}$ That the prosthesis outlives its user's body once again reveals the contrast between fragile body and tough device. The life of the mechanical part is shown to outlast the human whole, primarily because it is much more resilient.

The invulnerability of the false part was ruminated on again at the turn of the century in Wells's The Food of the Gods (1904). ${ }^{114}$ In this story, the farmer Mr. Skinner is eaten by a giant rat whose great size and appetite is effected from earlier eating the titular "food of the gods." When a search party is sent out for Skinner, the only part of him found is his glass eye. This motif was also present in Rudyard Kipling's short fiction "Mrs. Bathurst" (1904). ${ }^{115}$ Here, a charred corpse is identified as the body of a navy officer named Vickery in part because his four white artificial teeth are seen "shinin' against the black" of the carcass. ${ }^{116}$ The way in which these devices outlast their host exposes an apprehension that humans could be outlasted by a more resilient force: technology. As I show below, Parker's poem responds to various contemporary contexts, including 
debates concerning vitalism and the possibility of perpetual motion; the growth of the artificial limbs trade; the rise of industrial manufacture; and the development of automated machines, such as Babbage's "Difference Engine."

While Parker's poem is no doubt comical in its tone, it clearly reacts to trepidations about the splicing of a person with a thing. The technologically sophisticated object is shown to be too advanced for its user, since it demands more exercise than the human body can endure. Describing Turningvort's despair at hearing the pathologizing nature of his creation, the speaker explains:

His curious springs, wheels, cork, and leather,

By rarest art combined together,

Had done their work: and tho' by him

Perchance this superhuman limb

Might condescend to be directed,

It still might spurn to be subjected

To one, upon whose depth of science

It felt but moderate reliance[.] ${ }^{117}$

The device's agency but lack of sympathy underscores its inhumanity. Like an unruly piece of factory machinery, the leg has "a mind of its own" but is not sophisticated enough to deviate far from its primary function. The poem also shows the leg to be far more resilient that the body of the user, exacerbating the contrast between flesh and machine. The prosthetic leg is thus depicted as an uncontrollable mechanical other. In some ways, the poem exposes cultural misgivings about scientific authority. The worry is that, in an error of judgement, a scientist could produce a self-acting mechanical device that objects to being subservient to humankind. Here the false part, one employed to enable the user to pass as normal, quashes the user's agency, making him act oddly and unpredictably.

In this regard, the poem engages with contemporary debates related to life, energy, and the possibility of perpetual motion. Building on the division of the body and soul posited by Plato, Paracelsus, Jan Baptist van Helmont, Descartes, Georg Stahl, and the Montpellier school of medicine, eighteenth- and early nineteenth-century vitalist thinkers, such as Xavier Bichat, suggested that animal and organic life could be distinguished by a contrast between the forces of life and death. Bichat made the famous assertion that "life is the sum of the forces which resist death." 118 
Vitalism, "the theory that life is generated and sustained through some form of non-mechanical force or power specific to and located in living bodies," remained an influential yet contested biological philosophy throughout the nineteenth century. ${ }^{119}$ In his 1840s work on "the conservation of force," German surgeon and scientific philosopher Hermann von Helmholtz sought to disprove vitalist theories by demonstrating that perpetual motion - the possibility for which he claimed was implied by vitalist thinking-was not possible. ${ }^{120}$ As Helmholtz argued, "no perpetual motion is possible ... force cannot be produced from nothing, something must be consumed."121 Engaging with vitalism philosophy and problematizing John Locke's enduring emphasis on life "as the distinguishing character between men and machine," 122 Parker's poem reveals a Frankensteinian dread that a scientist could, by mistake, imbue a mechanical object with vitality, creating a conspicuously non-normative and nonhuman life form capable of threatening those who encounter it. Moreover, Parker's poem interrogates the vitalistic binary between animal life and the mechanical world, exploring the harmful potential of science gone wrong. Even more to the point, by displaying a prosthetic device that not only self-acts but animates without the need of a "moving force," Parker brings to the fore angst about mechanical devices that could move perpetually. ${ }^{123}$ We can also read Wodenblock's automatic prosthesis in relation to the real-life development of highly sophisticated mechanical devices. Contexts such as the opening of the Liverpool and Manchester Railway in 1830, Charles Babbage's continuing work in the 1820s and 1830s on the Difference Engine, and James Pott's invention of the Anglesey Leg in 1816 and its subsequent celebrity championing by the Marquess of Anglesey-a shifting into public view of artificial limbs that Vanessa Warne suggests "hints at the disquieting prominence of prosthetic legs in Victorian culture" - are all important factors. ${ }^{124}$

The opening of the Liverpool and Manchester railway on 15 September 1830 was both contemporaneous to the publication of The Flying Burgermaster and significant for bringing the human-technology relationship into public consciousness. The opening marked a new age of British transport and a celebration of the nation's technological achievements. By linking together two of Britain's most important industrial centres with a state-of-the-art technology designed to reduce journey times, the railway line promised to alter concepts of distance in the British imagination. A thousand passengers and almost a million onlookers attended the event. The crowds were already startled by the sheer speed of the new machines, 
which travelled at over thirty miles per hour (as fast as the quickest horses), but that was nothing compared to the shock caused by a fatal accident that marred the opening: Tory politician William Huskisson was struck by a train, causing a deadly leg break. The public display of mechanical brutality highlighted to the hordes in attendance and the millions who would read or hear about the incident afterwards what was already all too apparent to the contemporary factory worker: the new steam-powered machines were tremendously strong, unrelenting, and often outright dangerous. As much as these technologies could annihilate time and space, they could decimate the human body. ${ }^{125}$ Parker's image of a device that is also designed to enable locomotion, which affects the leg of a powerful local political figure and displays the ability of mechanical devices to run straight through human intervention, emerges as an imaginative response to Huskisson's contemporaneous accident. The mechanical prosthesis, a device designed to effect an appearance of completeness, appears as an ironic physical threat to organic wholeness.

Alongside the emerging spectacle of the railway and the unease it evoked, the question of the ability of the machine to think, a similarly threatening concept, was raised by Babbage's invention of the Difference Engine. Babbage came up with the idea for the Difference Engine in 1820 as a means with which to mechanize the production of mathematical tables. Despite encountering many difficulties along the way, by 1832 , with the help of his engineer Joseph Clement, Babbage had completed a small section of the Difference Engine, a machine that would sadly never be completed during the inventor's lifetime. Though not the first automatic machine-clocks, trains, and textile machinery all preceded it-the Difference Engine, as a concept more than a complete artefact, was significant as it brought to the fore the notion of machine intelligence. As Doron Swade writes: "[the Difference Engine] is a landmark in respect of the human activity it replaced. In the case of textile machines or trains, the human activity they replaced was physical. The 1832 engine represents an integration of machinery into psychology." ${ }^{126}$ Babbage himself stressed that his engine could not think per se, but its base organization "reflected the nervous system's structure as revealed by anatomists of the 1830s." 127 Despite this reserved approach, others later saw the Babbage's Difference and later Analytical Engine as devices that could replace the brain, an idea poignantly reinforced by Ada Lovelace's 1843 influential notes. ${ }^{128}$ Babbage's friend and barrister Harry Wilmot Buxton, who wrote Babbage's biography between 1872 and 1880 declared, "the marvellous 
pulp and fiber of a brain had been substituted by brass and iron ... [. Babbage] had taught wheel work to think, or at least to do the office of thought." 129 In the same way that Babbage brought concepts such as the machine and volition into conversation with one another, Parker's poem, and the stories of self-acting prostheses that proceeded it, drew from what were controversial materialist views, depicting mechanical devices whose proximity to the human was all too close and whose volition was all too strong. Simultaneously mechanical subjects and supplementary objects, these devices threatened to collapse the distinction between human and thing, part and whole.

A further important context for Parker's representation was the real-life development of artificial legs. As David M. Turner and Alun Withey discuss in their article on eighteenth-century technologies of the body, as early as the sixteenth century there emerged "a growing division between devices that were strictly functional, such as the peg legs doled out to poor amputee, and more sophisticated prosthetics that not only restored movement but actually resembled the missing body part."130 Pioneers of early sophisticated artificial limbs included Ambroise Paré. By the late eighteenth century, prosthetists such as Monsieur Laurent of Bouchain, Thomas Ranby Reid, and Thomas Mann were receiving high praise in newspapers for the high build quality and lifelike nature of their devices. However, it was not until after the Napoleonic Wars were over that artificial-limb developments became mainstream knowledge. The device that caught public attention was that worn by the First Marquess of Anglesey, a limb that became affectionately known as the Anglesey leg.

After Henry William Paget, at the time styled as the Earl of Uxbridge, lost his leg to grapeshot in the Battle of Waterloo in 1815, he turned to Chelsea Hospital prosthetist James Potts for a device that could stand in for his lost limb. Potts, who was the first man to patent a wooden leg articulated at the knee, ankle, and toe joints in 1805, produced an artificial leg crafted to an elegant and lifelike form. It contrasted the rudimentary shape of peg legs, which, despite the early development of artificial legs, remained the preferred type of lower-limb prosthesis up until this point. As Paul Youngquist writes: "Potts's work was top-notch, and he created a noble leg for a noble patriot." 131 His device, which came to be known as the Anglesey leg, served as a model for the development of numerous patented artificial limbs as the trade ascended in Europe and America over the course of the nineteenth century. At a time when England was reportedly replete with amputees during the aftermath of the Napoleonic Wars 
(1803-1815), ${ }^{132}$ The Flying Burgermaster responded to the issue of rehabilitation by imagining a hyperbolized version of a prosthesis like the Anglesey leg as a technology so astonishingly sophisticated that it could override the will of its user.

Drawing from similar contexts to The Flying Burgermaster, appearing first in the 1820s or 1830s, the oft-repeated popular "Cork Leg" narrative was also written in a comical style, and told more or less the same story as Parker's poem. A poetic version has been attributed by many to Thomas Hudson, with potentially the earliest (though anonymous) recorded version of it dated between 1819 and 1844 in the Bodleian Library. ${ }^{133}$ However, a prose version by Henry G. Bell, entitled "The Marvellous History of Mynheer von Wodenblock," was published in Edinburgh Literary Journal in 1829 and subsequently reprinted in the same author's book My Old Portfolio; or Tales and Sketches in 1832. ${ }^{134}$ The story was so popular that it was set to music by Jonathan Blewitt around 1830 (see Fig. 3.1) and was reprinted numerous times in both verse and prose form. Like Parker's poem, the various incarnations of "Cork Leg" drew from contemporary trepidation about machine volition. In the version published in Ashton's collection, like Wodenblock, Mynheer von Clam, the amputated protagonist of "Cork Leg," puts faith in the mimetic capacities of technology, declaring "on two crutches I'll never stalk,/For I'll have a beautiful leg of cork." ${ }^{35}$ In this poem we get an even greater sense of the sophistication of the prosthesis:

Each joint was as strong as an iron beam,

The springs a compound of clockwork and steam.

The fine shape gave Mynheer delight,

And he fixed it on and screwed it tight. ${ }^{136}$

In the same manner that Wodenblock and John A. B. C. Smith attach their limbs, Mynheer screws his leg on. This mechanical mode of attaching the prosthesis emphasizes its non-humanness, making its ability to self-act even more disconcerting. The act of screwing is very much associated with the joining together of fabricated objects for the purposes of construction. Yet, as Green points out, screws were rarely used in the nineteenth century except in large industrial contexts such as factories. ${ }^{137}$

This fact brings to the fore a link between these narratives and anxieties regarding the factory system. Humans tend not to be threaded thus this act suggests a process of mechanization on the part of the prosthesis user. 


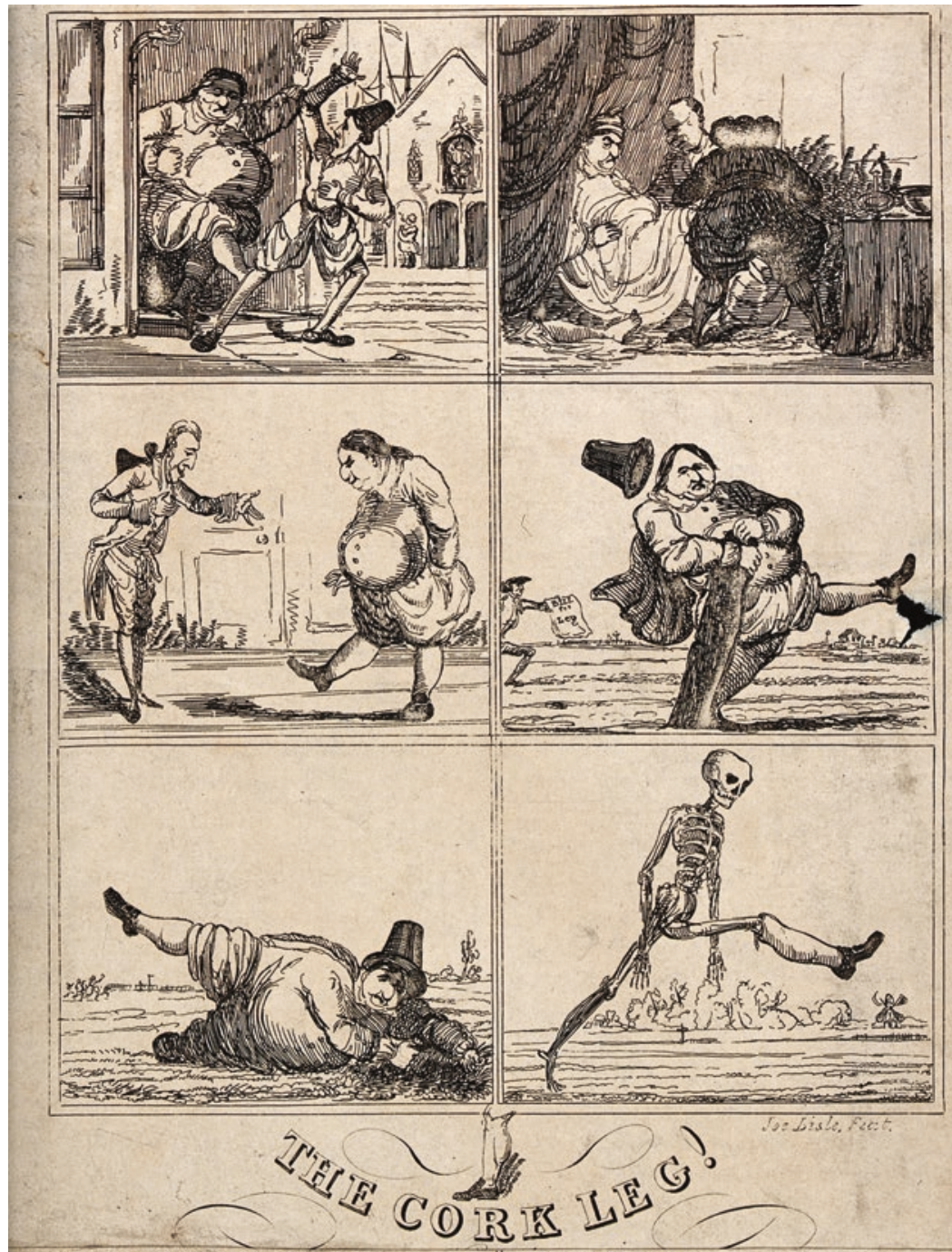

An Artist in Rotteriam 'twould seem

Had made Cork legs his study and theme Q $u$ h joint was as strongas an iron beam The springs a compount of clockwork ás steam.
He wall'd of days and nights a score Of Europe he had made the tour Ho died but tho' he was no more The Leg walk'd on the same as before.

Fig. 3.1 A cartoon etched by Joe Lisle to advertise "The Cork Leg," set to music by the composer Jonathan Blewitt. Joe Lisle after Jonathan Blewitt, Six Scenes Narrating the Fate of a Cork Leg, the Invention of a Dutch Artist, c. 1830, etching with engraving, Wellcome Collection, London. Image courtesy of the Wellcome Collection. https://wellcomecollection.org/works/gfb88ffh. CC BY 4.0 
These depictions thus echo Karl Marx's warning, expressed most famously in Capital (1867), that the factory system renders humans a mere appendage of the machine at which they work. ${ }^{138}$ "The Cork Leg" drew from contemporary apprehensions about the human-machine relationship while bringing into focus a comically pitched but nonetheless topically profound challenge to human agency. The unruly prosthetic body part threatens the agency and health of those who attempt to imitate bodily norms. The powerful prosthetic, artificial and partial, challenges the dominance of organic wholeness by asserting an unwillingness to allow its user simply to pass as normal. Instead, it effects an agenda of its own.

By the early twentieth century, following over half a century of developments in prosthetic limbs, we see the self-acting prosthesis reimagined in equally comical yet voguishly sinister terms. In The Cinema of Isolation, Martin F. Norden shows how early twentieth-century film frequently draws on nineteenth-century tropes and stereotypes, using issues related to disability as exploitable material. ${ }^{139}$ As I show, motion pictures from this period also rework narratives that engage with extant concerns about human-machine relationships, using the visual medium of film to provoke new responses regarding self-acting limbs. Moreover, by engaging with the well-established hegemony of organic physical wholeness, these depictions suggest the idea that this dominance could be challenged by increasingly intelligent and sophisticated technologies.

In The Thieving Hand, a 1908 film directed and produced by J. Stuart Blackton, another self-acting prosthesis is portrayed. Once again in the comic mode, here a false arm is imagined that displays an insatiable propensity to steal. The arm is bought as a reward for an honest street beggar who returns a dropped watch to a philanthropic passer-by. Amusingly, the arm is purchased in a high-street artificial limb shop, hyperbolizing the increased commercialization and availability of these products in the early twentieth century. Both the homeless man and the wealthy buyer of the limb are enthralled by the sophisticated arm that they are shown, which not only looks like an organic human arm but also moves like one after it has been wound up using a removable crank handle-a practice that reflects the way that petrol-powered automobile engines were started in this period. ${ }^{140}$ Most miraculously, the arm moves independently from a user's body. However, as soon as the limb is purchased, for what appears a large sum, the arm squirms uncontrollably and soon starts to rob anyone and anything within sight. The arm initially steals a handkerchief from the generous purchaser of the limb, but when it attempts to remove the gentleman's tie, the user stops it. On the street, the limb robs several 
passers-by, who in return show scorn towards the unwitting beggar. Tired of being branded a thief, the tramp sells his arm to a pawnbroker. In the pawnbroker's shop, the arm not only attacks the owner but also steals all it can from the shop's display before crawling back and reattaching itself to its original user. Furious at finding the false limb and his most valuable items missing, the pawnbroker tells a police officer and together the pair track down and arrest the innocent user. The homeless man is then placed in a communal jail cell, where his false arm attaches itself to a criminal who also happens to be an arm amputee.

There are several obvious similarities between Blackton's film and a nineteenth-century street ballad that was printed alongside "Cork Leg" in John Ashton's 1888 collection. In “The Thief's Arm” (1888), an amputee war veteran is fitted with the arm of a deceased criminal. ${ }^{141}$ Like the false arm in The Thieving Hand, this limb turns out to have an agency of its own. While attached to the body of the veteran, it unrelentingly steals wherever the subject goes. After the war veteran is arrested and executed for his arm's crimes, the arm rises and joins "a body-snatching knave,/ Who stole his master out of his grave." 142 Though the arm depicted in this poem is not mechanical, it nonetheless acts in a very similar way to the limb portrayed in The Thieving Hand. It is possible that the poem provided inspiration for the short film. Another possible influence was the popular song "The Steam Arm" (c.1835), which Kirstie Blair considers as a protosteampunk narrative. ${ }^{143}$ While "The Thief's Arm" reveals fear of a morally corrupt medical profession-one which recklessly transplants arms and digs up the bodies of deceased paupers for experimentation-Blackton's film presents a more nuanced satire of the prosthesis industry, which by the early twentieth century was well-established and truly international.

The visual effects used by Blackton in The Thieving Hand complicate the distinct binary between human body and false part that is made manifest in the earlier representations of self-acting prostheses. For its time, Blackton's film is visually impressive, providing some very convincing stop-motion animation in places. In other instances, a real arm poses as the prosthetic, in practical terms reversing the primary function of a false limb. Here, a real limb stands in for a false one, rather than vice versa. This visual blurring of organic and artificial limb not only serves a practical purpose- the use of a real arm enables a convincing deception-but also makes the mechanical prosthesis look more intelligent and potentially more threatening than the previous self-acting devices. While the earlier portrayals of self-acting artificial legs tirelessly repeat the same stock 
motion repeatedly, here the "thieving hand" shows initiative and adaptability as it performs more than just one task-it fights the pawnbroker, strokes the same gentleman's head, escapes from a shop, drags itself along the floor, attaches and reattaches itself to two different users, and employs a range of tactics and techniques to steal from various people. We can thus consider this device as unruly yet intelligent. The prosthesis disrupts not only the life of its user but also the lives of a great number of other people, including those whom it steals from. Since it truly does possess a mind of its own, this prosthesis provides a threat to the normative order of human society. The film, in a light-hearted fashion, brings to the fore a cinematic trope of conflict between human and machine, a theme that continues to drive modern narratives-see, for instance, Alex Proyas's I, Robot (2004) or any of the films from the Terminator franchise. ${ }^{144}$ To this day, we remain haunted by the spectre of machine agency.

Covering a wide array of writings from across the period that this book investigates, this chapter has exposed the various ways in which literary narratives conceptualized how human autonomy was affected by prosthesis use. While the literary works from this period responded to many distinct historical factors, including international conflicts, technological developments, and shifting understandings of personhood, what binds the representations discussed here is that they each interrogate the hegemony of physical wholeness. Though often tinged by ableism, the representations discussed here either expose the process of prostheticizing as flawed or present powerful non-normative challenges to contemporary bodily ideals. The autonomy of the prosthetic part and the human-machine hybrid are presented as threats to the normative organic body, even though both are products of ableist pressures that encouraged prostheses for passing. In the context of the literary narratives discussed, the concept of prosthesis as a disciplinary tool used to enforce and maintain bodily standards collapses as it brings about new threatening and conspicuously nonnormative agencies. To borrow a phrase from literary historian Patricia Murphy, the supremacy of the physically complete body was being "attenuated even as [it was] being valorised." 145

\section{Notes}

1. Nick Park, Wallace and Gromit: The Wrong Trousers, BBC, 1993.

2. Erin O'Connor, Raw Material: Producing Pathology in Victorian Culture (Durham: Duke University Press, 2000), 106. 
3. Tamara Ketabgian, The Lives of Machines: The Industrial Imaginary in Victorian Literature and Culture (Ann Arbor: University of Michigan Press, 2011), 2.

4. [Frances Parker], the Countess of Morley, The Flying Burgermaster: A Legend of the Black Forest (n.p.: F. Morley, 1832); [Thomas Hudson,?], "Cork Leg," in Modern Street Ballads, ed. John Ashton (London: Chatto \& Windus, 1888); J. Stuart Blackton, The Thieving Hand, Vitagraph Company of America, 1908, YouTube, accessed June 16, 2018, https://www.youtube.com/watch?v=J2Dr0MBWXgQ.

5. Jacques Derrida, “That Dangerous Supplement," in Of Grammatology, by Jacques Derrida (Baltimore: John Hopkins University Press, 1997), 144.

6. Ketabgian, The Lives, 19.

7. See Laura Otis, Networking: Communicating with Bodies and Machines in the Nineteenth Century (Ann Arbor: University of Michigan Press, 2001), 9-10; Nicholas Daly, Literature, Technology, and Modernity, 1860-2000 (Cambridge: Cambridge University Press, 2004), 10-33; Martin Willis, Mesmerists, Monsters, and Machines: Science Fiction and the Cultures of Science in the Nineteenth Century (Kent: Kent State University Press, 2006), 98-114; Herbert Sussman, Victorian Technology: Invention, Innovation, and the Rise of the Machine (Santa Barbara: ABC-CLIO, 2009), 39-51; Ketabgian, The Lives, 51-54; and Roger Smith, Free Will and the Human Sciences in Britain, 1870-1910 (London: Pickering \& Chatto, 2013), 1-8.

8. Thomas Henry Huxley, "On the Hypothesis That Animals Are Automata and Its History," Nature 10 (1874).

9. Andrew Ure, The Philosophy of Manufactures; or, an Exposition of the Scientific, Moral and Commercial Economy of the Factory System of Great Britain (London: C. Knight, 1835), 367.

10. Charles Babbage, An Essay on the General Principles Which Regulate the Application of Machinery to Manufactures and the Mechanical Arts (London: W. Clowes, 1827), 6.

11. Julien Offray de La Mettrie, L'Homme Machine (Paris: F. Henry, 1865); Jenny Uglow, "Introduction: 'Possibility," in Cultural Babbage: Technology, Time and Invention, ed. Francis Spufford and Jenny Uglow (London: Faber and Faber, 1997), 16.

12. Anson Rabinbach, The Human Motor: Energy, Fatigue, and the Origins of Modernity (Berkeley: University of California Press, 1990), 2.

13. See Lorraine J. Daston, "British Responses to Psycho-Physiology, 1860-1900," Isis 69, no. 2 (1978); Sally Shuttleworth and Jenny Bourne Taylor, eds., Embodied Selves: An Anthology of Psychological Texts 1830-1890 (Oxford: Oxford University Press, 1998); Rick Rylance, 
Victorian Psychology and British Culture: 1850-1880 (Oxford: Oxford University Press, 2000); and Smith, Free Will.

14. Mary Shelley, Frankenstein, or the Modern Prometheus (London: Norton, 1996); Daniel Dinello, Science Fiction Visions of Posthuman Technology (Austin: University of Texas Press, 2005), 41.

15. Daly, Literature, 1; Dion Boucicault, After Dark: A Drama of London Life in 1868, in Four Acts (New York: De Witt Publishing House, 1868).

16. John Plunkett et al., eds., Victorian Literature: A Sourcebook (Basingstoke: Palgrave Macmillan, 2011), 274.

17. Charles Dickens, Dombey and Son (London: Penguin, 2002); Charles Dickens, “The Signal Man," All the Year Round 16, no. 400 (1866).

18. H. G. Wells, The Time Machine (Oxford: Oxford University Press, 2017); H. G. Wells, The Island of Dr. Moreau (London: Broadview, 2009); H. G. Wells, The Invisible Man (London: Penguin, 2005); H. G. Wells, When the Sleeper Wakes, Project Gutenberg, last modified September 17, 2016, http://www.gutenberg.org/files/775/775-h/775-h.htm.

19. Edgar Allan Poe, "The Man That Was Used Up: A Tale of the Late Bugaboo and Kickapoo Campaign," in The Works of the Late Edgar Allan Poe, by Edgar Allan Poe, vol. 4 (New York: Blakeman \& Mason, 1859); Herman Melville, Moby-Dick (London: Penguin, 2012).

20. Thomas Hood, Miss Kilmansegg and her Precious Leg. In Selected Poems of Thomas Hood, ed. John Clubbe (Cambridge: Harvard University Press, 1970); Arthur Conan Doyle, The Sign of Four (Garches: Feedbooks, n.d.).

21. O’Connor, Raw Material, 123.

22. Ibid., 125.

23. Charles Dickens, The Pickwick Papers (New York: Hurd and Houghton, 1870). Charles Dickens, Our Mutual Friend (London: Everyman, 2000); Anthony Trollope, He Knew He Was Right (Oxford: Oxford University Press, 2008).

24. "A Romance of War," Kind Words, May 1, 1872: 145.

25. "Peg-Legged Bob," All the Year Round 11, no. 280 (1874).

26. See, for instance, Lisa Herschbach, "Prosthetic Reconstruction: Making the Industry, Re-Making the Body, Modelling the Nation," History Workshop Journal 44 (1997); David D. Yuan, "Disfigurement and Reconstruction in Oliver Wendell Holmes's 'The Human Wheel, Its Spokes and Felloes,'” in The Body and Physical Difference: Discourses of Disability, eds. David T. Mitchell and Sharon L. Snyder (Ann Arbor: University of Michigan Press, 1997); Stephen Mihm, "'A Limb Which Shall Be Presentable in Polite Society': Prosthetic Technologies in the Nineteenth Century," in Artificial Parts, Practical Lives: Modern Histories of Prosthetics, eds. Katherine Ott, David Serlin, and Stephen Mihm (New York: New York University Press, 2002); and Guy R. Hasegawa, Mending 
Broken Soldiers: The Union and Confederate Programs to Supply Artificial Limbs (Carbondale: Southern Illinois University Press, 2012).

27. Oliver Wendell Holmes, "The Human Wheel, Its Spokes and Felloes," Sounds from the Atlantic, by Oliver Wendell Holmes (Boston: Ticknor and Fields, 1864), 324.

28. M. E. Francis, "A Rustic Argus," Longman's Magazine 35, no. $210(1900)$.

29. Katherine Ott, "Hard Wear and Soft Tissue: Craft and Commerce in Artificial Eyes," in Artificial Parts, Practical Lives: Modern Histories of Prosthetics, eds. Katherine Ott, David Serlin, and Stephen Mihm (New York: New York University Press, 2002), 153-54. Also see I. den Tonkelaar, H. E. Henkes, and G. K. Van Leersum, "Herman Snellen (1834-1908) and Müller's 'Reform-Auge': A Short History of the Artificial Eye," History of Ophthalmology 4 (1991).

30. "Nineteenth- and Twentieth-Century Prostheses," The College of Optometrists, accessed June 20, 2018, https://www.collegeoptometrists.org/the-college/museum/online-exhibitions/virtualartificial-eyes-gallery/19th-and-20th-century-prostheses.html.

31. O'Connor, Raw Material, 132-35.

32. Poe, "The Man," 315-16.

33. Ibid., 317.

34. Ibid., 325.

35. James Berkley, "Post-Human Mimesis and the Debunked Machine: Reading Environmental Appropriation in Poe's 'Maelzel's Chess-Player' and 'The Man That Was Used Up,'” Comparative Literature Studies 41, no. 3 (2004): 372.

36. O'Connor, Raw Material, 132.

37. William Makepeace Thackeray, "The Notch on the Ax-a Story a La Mode," Roundabout Papers, by William Makepeace Thackeray (Sydney: ReadHowYouWant, 2009).

38. Katherine Ott, "The Sum of Its Parts: An Introduction to Modern Prosthetics," in Artificial Parts, Practical Lives: Modern Histories of Prosthetics, ed. Katherine Ott, David Serlin, and Stephen Mihm (New York: New York University Press, 2002), 26.

39. Vanessa Warne, “If You Should Ever Want an Arm': Disability and Dependency in Edgar Allan Poe's 'The Man That Was Used Up,'” Atenea 25, no. 1 (2005): 104.

40. Douglas Bly, A Description of a New, Curious, and Important Invention (Rochester: Rochester Evening Express, 1859), 6.

41. Kevin J. Hayes, "Visual Culture and the Word in Edgar Allan Poe's 'The Man of the Crowd," Nineteenth-Century Literature 56, no. 4 (2002): 458 . 
42. Ernest G. Henham, "A Human Bundle," Temple Bar 111, no. 438 (1897). See the intro to Chapter 2 and Ryan Sweet, "'A Human Bundle': The Disaggregated Other at the Fin de Siècle," Victorian Review 40, no. $1(2014)$.

43. "Wooden Legs," The Court Magazine and Belle Assemblee 2, no. 3 (1833).

44. Such cruel humour mirrors Simon Dickie's observations about physical difference remaining an accepted topic for jests up until the midnineteenth century. Simon Dickie, "Hilarity and Pitilessness in the MidEighteenth Century: English Jestbook Humor," Eighteenth-Century Studies 37, no. l (2003): 18.

45. Vanessa Warne, “'To Invest a Cripple with Peculiar Interest': Artificial Legs and Upper-Class Amputees at Mid-Century," Victorian Review 35, no. 2 (2009); Ryan Sweet, "Get the Best Article in the Market': Prostheses for Women in Nineteenth-Century Literature and Commerce," in Rethinking Modern Histories of Prostheses in Anglo-American Commodity Cultures, 1850-1960, ed. Claire L. Jones (Manchester: Manchester University Press, 2017).

46. John Woodforde, The Strange Story of False Teeth (London: Routledge and Kegan Paul, 1968), 87-92.

47. "Too Hard Upon My Aunt," All the Year Round 10, no. 242 (1863).

48. “The Wig Wouldn't Work like the Natural," Illustrated Chips 10, no. 248 (1895): 3 .

49. Ibid., 3 .

50. In terms of Ahab's representation, Mitchell and Snyder write, "Ahab's dismemberment and 'incomplete' physicality-now simulated with a whalebone substitute-supplies Melville's characterization with both a personal motive and an identifying physical mark. These two aspects function in the novel as a deterministic shorthand device for signifying the meaning of Ahab's being." David T. Mitchell, and Sharon L. Snyder, Narrative Prosthesis: Disability and the Dependencies of Discourse (Ann Arbor: University of Michigan Press, 2000), 123.

51. Melville, Moby-Dick, 538.

52. Ibid., 144.

53. Ibid., 197.

54. Ibid., 147, 114; Mitchell and Snyder, Narrative Prosthesis, 122.

55. Melville, Moby-Dick, 187.

56. Ibid., 82 .

57. Ibid., 270.

58. Ibid., 492.

59. Ibid., 511.

60. Ibid., 512-13.

61. Ibid., 511. 
62. George E. Marks, Marks' Patent Artificial Limbs with Rubber Hands and Feet (New York: A. A. Marks, 1888), 9.

63. Henry Heather Bigg, On Artificial Limbs, Their Construction and Application (London: John Churchill, 1855), 73.

64. Melville, Moby-Dick, 511.

65. Ibid., 511 .

66. The Walking Dead, AMC, 2010-; Planet Terror, directed by Robert Rodriguez (2007; Toronto: Entertainment One, 2008), DVD. There are numerous other examples of weaponized prosthetics in late twentieth and early twenty-first-century culture. For instance, we can add to this list Ash's chainsaw hand in Evil Dead II, directed by Sami Raimi (1987; Issyles-Moulineaux: Studiocanal, 2019), DVD; Big Louie's meat cleaver hand attachments in UHF, directed by Jay Levey (1989; Beverly Hills: MGM, 2002), DVD; the minigun arm of the protagonist of The Machine Gun Girl, directed by Noboru Iguchi (2008; New York: Tokyo Shock, 2011), DVD; and Gazelle's blade legs in Kingsman: The Secret Service, directed by Matthew Vaughn (2014; Beverly Hills: Twentieth Century Fox Home Entertainment, 2015), DVD.

67. Nelly Oudshoorn, and Trevor Pinch, eds., How Users Matter: The Co-Construction of Users and Technology (London: Massachusetts Institute of Technology Press, 2003), 4; Ruth Schwartz Cowan, “The Industrial Revolution in the Home: Household Technology and Social Change in the Twentieth Century," Technology and Culture 17 (1976).

68. Oudshoorn and Pinch, How Users, 1.

69. "The Use of a Wig-a Hint to the Ladies," The Satirist; or, the Censor of the Times 675 (1845): 90.

70. “The Lame Landlord's Story," Temple Bar 20 (1867): 131.

71. Mark Twain, Roughing It (London: Penguin, 1988), 403.

72. "How He Turned It with His Wooden Leg," Illustrated Chips 258 (1895): 4-5.

73. Tobin Siebers, "Disability as Masquerade," Literature and Medicine 23, no. 1 (2004): 5 .

74. “The Advantages of Having False Teeth," Judy, January 27, 1904, 664.

75. Blind Man's Bluff, directed by Arthur Cooper (1903; Alpha Trading Company).

76. Henry Clay Lewis, “The Indefatigable Bear Hunter” in Louisiana Swamp Doctor: The Writings of Henry Clay Lewis, ed. John Q. Anderson (Baton Rouge: Louisiana State University Press, 1962); R. M. Ballantyne, Why I Did Not Become a Sailor, in Freak on the Fells; or Three Months' Rustication and Why I Did Not Become a Sailor, by Robert Michael Ballantyne (Philadelphia: The John Winston Co., 1864); D. B. McKean, “A Wig and a Wooden Leg," Chatterbox 4 (1886): 27; 
77. "New Use for a Wooden Leg," Nottinghamshire Guardian, June $17,1899$.

78. "Wooden Leg as Weapon," Daily Mail, January 12, 1904, 3. A similar scene was also depicted in Cooper's Blind Man's Bluff.

79. For more on Miss Kilmansegg's popularity, see Warne, "To Invest," 95-96. For more on the poem's message about prostheses to avoid, see Sweet, "Get the Best."

80. Hood, Miss Kilmansegg, 782 and 785.

81. Ibid., 1042-45.

82. Ibid., 2211.

83. Ibid., 944-1224.

84. Ibid., 1933-34.

85. Ibid., 2353-59.

86. Lewis, "The Indefatigable," 235.

87. Ibid., 238.

88. Ibid., 238.

89. Ibid., 242.

90. Ibid., 244.

91. Ibid.

92. Ibid.

93. Ibid., 241.

94. Ibid., 236.

95. Harvey Green, Wood: Craft, Culture, History (London: Penguin, 2007), 316.

96. Doyle, The Sign, 13.

97. Ibid., 100.

98. Ibid., 100-101.

99. Ibid., 103.

100. Madeleine Akrich, "The De-Scription of Technical Objects," in Shaping Technology/Building Society: Studies in Sociotechnical Change, eds. Wiebe E. Bijker and John Law (Cambridge: Massachusetts Institute of Technology Press, 1992), 209. "Projected users" are created by and shape the work of designers of technology. As Christina Lindsay describes, "Projected users are defined with specific tastes, competencies, motives, aspirations, and political prejudices." "The innovators," Lindsay explains, "then inscribe this vision or script about the world and about the users into the technical content of the object, and thus attempt to predetermine, or prescribe, the settings the users are asked to imagine for a particular piece of technology. The prediction about the user is thus built into, or scripted into, the technology." Christina Lindsay, "From the Shadows: Users as Designers, Producers, Marketers, Distributors, and Technical Support," in How Users Matter: The Co-Construction of Users 
and Technology, ed. by Nelly Oudshoorn and Trevor Pinch (London: Massachusetts Institute of Technology Press, 2003), 31.

101. Jenny Morris, Pride Against Prejudice: Transforming Attitudes to Disability (London: The Women's Press, 1996), 93.

102. Mitchell and Snyder, Narrative Prosthesis, 135.

103. David A. Gerber, ed., Disabled Veterans in History, enlarged and revised ed. (Ann Arbor: University of Michigan Press, 2012), 36.

104. Critically, though, Marten highlights a correlation between alcoholism and crime within veteran populations, suggesting that a combination of exposure to trauma and numerous social and economic conditions drove many to drink, which in turn exacerbated crime statistics. James Marten, "Nomads in Blue: Disabled Veterans and Alcohol at the National Home," in Disabled Veterans in History, ed. David A. Gerber, enlarged and revised ed. (Ann Arbor: University of Michigan Press, 2012), 325.

105. Cesare Lombroso, Criminal Man, ed. and trans. Mary Gibson and Nicole Hahn Rafter (Durham: Duke University Press, 2006), 164.

106. "The Advantages," 664.

107. "Bolderoe's Widow," All the Year Round 17, no. 413 (1876); Allsopp Æsop, "The Wooden Leg and the Ungrateful Pensioner," Funny Folks 177 (1878): 126; "A Wooden Leg That Knows a Thing or Two," Every Week: A Journal of Entertaining Literature 53, no. 1355 (1895): 21; Frank Crane, "Willie Westinghouse Invents an Automatic Arm," The Wichita Daily Eagle, 10 April 1904; Frank Crane, "Willie's 'Handshaker' Gets Papa into Trouble," The San Francisco Call, 7 April 1907.

108. [Parker], The Flying, no lines.

109. Ibid.

110. Ibid.

111. Ibid.

112. Ibid.

113. Ibid. For more on this legend and its reception history, see George Kumler Anderson, The Legend of the Wandering Jew (Providence: Brown University Press, 1965). A similar refashioning of this legend appeared in Chambers's Journal. "The Wandering Jew," Chambers's Journal of Popular Literature, Science and Arts 9, no. 458 (1862).

114. H. G. Wells, The Food of the Gods and How It Came to Earth, Project Gutenberg, last modified August 14, 2010, http://www.gutenberg.org/ cache/epub/11696/pgl1696-images.html.

115. Rudyard Kipling, "Mrs. Bathurst," in Rudyard Kipling, Traffics and Discoveries (New York: Charles Scribner's Sons, 1909).

116. Ibid., 407.

117. [Parker], The Flying, no lines.

118. Qtd. and trans. in A. S. Weber, ed., Nineteenth-Century Science: $A$ Selection of Original Texts (Peterborough: Broadview, 2000), 7. 
119. Catherine Packham, Eighteenth-Century Vitalism: Bodies, Culture, Politics (Basingstoke: Palgrave Macmillan, 2012), 1.

120. Weber, Nineteenth-Century, 278-79.

121. Hermann von Helmholtz, "On the Conservation of Force," in Nineteenth Century Science: A Selection of Original Texts, ed. A. S Weber, trans. E. Atkinson et al. (Peterborough: Broadview, 2000), 298.

122. Packham, Eighteenth-Century, 16.

123. Helmholtz, "On the Conservation," 282.

124. Warne, "To Invest," 29.

125. See Rebecca Solnit, "The Annihilation of Time and Space," New England Review 24, no. 1 (2003).

126. Doron Swade, “'It will not slice a pineapple': Babbage, Miracles and Machines," in Cultural Babbage: Technology, Time and Invention, ed. Francis Spufford and Jenny Uglow (London: Faber and Faber, 1997), 47.

127. Otis, Networking, 33.

128. L. F. Menabrea, "Sketch of the Analytical Engine Invented by Charles Babbage," trans. and notes Ada Lovelace, Scientific Memoirs 3 (1843), 666-731.

129. Harry Wilmot Buxton, Memoir of the Life and Labours of the Late Charles Babbage Esq., F.R.S. (Cambridge: Massachusetts Institute of Technology Press, 1988), 48-49; qtd. in Otis, Networking, 33.

130. David M. Turner and Alun Withey, "Technologies of the Body: Polite Consumption and the Correction of Deformity in Eighteenth-Century England," History 99, no. 338 (2014): 784.

131. Paul Youngquist, Monstrosities: Bodies and British Romanticism (Minneapolis: Minnesota University Press, 2003), 184.

132. Adrienne E. Gavin, "Dickens, Wegg, and Wooden Legs," Our Mutual Friend: The Scholarly Pages, accessed June 18, 2018, http://omf.ucsc. edu/london-1865/victorian-city/wooden-legs.html.

133. [Thomas Hudson], "The Cork Leg," [1819-1844] Broadside Ballads Online, accessed June 21, 2018, http://ballads.bodleian.ox.ac.uk/ view/edition/5413.

134. Henry G. Bell, “The Marvellous History of Mynheer Von Wodenblock," The Edinburgh Literary Journal, or, Weekly Register of Criticism and Belles Lettres, no. 47 (1829): 248-49; Henry G. Bell, My Old Portfolio; or Tales and Sketches (London: Smith, Elder, and Co., 1832); Ray Girvan, "HG Bell: The First Cyborged Leg?" JSBlog - Journal of a Southern Bookreader, last modified July 6, 2011, http://jsbookreader.blogspot. com $/ 2011 / 07 /$ hg-bell-first-cyborged-leg.html.

135. [Hudson], “Cork Leg," no lines.

136. Ibid.

137. Green, Wood, 65 and 118-19. 
138. Karl Marx, Capital: A Critical Analysis of Capitalist Production, trans. Samuel Moore and Edward Aveling (London: Kimble \& Bradford, 1938). Also see Ketabgian, The Lives, 19-29.

139. Martin F. Norden, The Cinema of Isolation: A History of Physical Disability in the Movies (New Brunswick: Rutgers University Press, 1994).

140. See Joseph J. Corn, User Unfriendly: Consumer Struggles with Personal Technologies, from Clocks and Sewing Machines to Cars and Computers (Baltimore: John Hopkins University Press, 2011), 94-95.

141. "The Thief's Arm," in Modern Street Ballads, ed. John Ashton (London: Chatto \& Windus, 1888).

142. Ibid., no lines.

143. "The Steam Arm," in “'The Steam Arm': Proto-Steampunk Themes in a Victorian Popular Song," by Kirstie Blair, Neo-Victorian Studies 3 (1) 2010: 204-205. In Blair's words, “'The Steam Arm” ... is an anonymous ballad that appears to date from just before Victoria's accession to the throne. It relates the story, in the third person, of a one-armed Waterloo veteran, beaten by his 'arrant scold' of a wife, who determines to get even with her by replacing his lost arm with a mechanical steam-powered limb. The prosthetic arm is successfully grafted on to his stump, but once in action, it turns out to be too successful, not only striking down his wife, but the police who come to arrest him, the mayor who tries him, and the walls of the cell in which he is imprisoned. In the second-to-last stanza the hero attempts to return home and take his wife in his arms, but as his steam arm 'smash'd the crockery ware,' its incompatibility with love and domesticity is apparent. The soldier is finally doomed to remain alienated from all society, a haunting figure wandering 'like a sprite,' while 'his arm keeps moving with two-horse might." Kirstie Blair, "'The Steam Arm': Proto-Steampunk Themes in a Victorian Popular Song," Neo-Victorian Studies 3, no. 1 (2010): 196. Clear narrative and thematic overlaps with Hudson's “Cork Leg” and Parker's The Flying Burgermaster are apparent.

144. I, Robot, directed by Alex Proyas (2004; Walt Disney Studios HE, 2004), DVD.

145. Patricia Murphy, “The Fissure King: Parody, Ideology, and the Imperialist Narrative," in The Victorian Comic Spirit: New Perspectives, ed. Jennifer A. Wagner-Lawlor (Aldershot: Ashgate, 2000).

\section{REFERENCES}

“The Advantages of Having False Teeth". Judy, Jan. 27, 1904.

Æsop, Allsopp. “The Wooden Leg and the Ungrateful Pensioner.” Funny Folks 177 (1878): 126.

Akrich, Madeleine. "The De-Scription of Technical Objects." In Shaping Technology/Building Society: Studies in Sociotechnical Change, edited by Wiebe 
E. Bijker and John Law, 205-24. Cambridge: Massachusetts Institute of Technology Press, 1992.

Anderson, George Kumler. The Legend of the Wandering Jew. Providence: Brown University Press, 1965.

Babbage, Charles. An Essay on the General Principles Which Regulate the Application of Machinery to Manufactures and the Mechanical Arts. London: W. Clowes, 1827.

Ballantyne, R. M. Why I Did Not Become a Sailor. In Freak on the Fells; or Three Months' Rustication and Why I Did Not Become a Sailor, by Robert Michael Ballantyne, 263-379. Philadelphia: The John Winston Co., 1864.

Bell, Henry G. "The Marvellous History of Mynheer Von Wodenblock." The Edinburgh Literary Journal, or, Weekly Register of Criticism and Belles Lettres, no. 47 (1829): 248-49.

—. My Old Portfolio; or Tales and Sketches. London: Smith, Elder, and Co., 1832.

Berkley, James. "Post-Human Mimesis and the Debunked Machine: Reading Environmental Appropriation in Poe's 'Maelzel's Chess-Player' and 'The Man That Was Used Up.'” Comparative Literature Studies 41, no. 3 (2004): 356-76.

Bigg, Henry Heather. On Artificial Limbs, Their Construction and Application. London: John Churchill, 1855.

Blackton, J. Stuart. The Thieving Hand. Veitagraph Company of America, 1908. YouTube. Accessed June 16, 2018. https://www.youtube.com/ watch?v=J2Dr0MBWXgQ.

Blair, Kirstie. “'The Steam Arm': Proto-Steampunk Themes in a Victorian Popular Song." Neo-Victorian Studies 3, no. 1 (2010): 196-207.

Bly, Douglas. A Description of a New, Curious, and Important Invention. Rochester: Rochester Evening Express, 1859.

"Bolderoe's Widow". All the Year Round 17, no. 413 (1876): 157-68.

Boucicault, Dion. After Dark: A Drama of London Life in 1868, in Four Acts. New York: De Witt Publishing House, 1868.

Buxton, Harry Wilmot. Memoir of the Life and Labours of the Late Charles Babbage Esq., F.R.S. Cambridge: Massachusetts Institute of Technology Press, 1988.

Cooper, Arthur, dir. Blind Man's Bluff. 1903; Alpha Trading Company.

Corn, Joseph J. User Unfriendly: Consumer Struggles with Personal Technologies, from Clocks and Sewing Machines to Cars and Computers. Baltimore: John Hopkins University Press, 2011.

Cowan, Ruth Schwartz. "The Industrial Revolution in the Home: Household Technology and Social Change in the Twentieth Century." Technology and Culture 17 (1976): 1-23.

Crane, Frank. "Willie Westinghouse Invents an Automatic Arm." The Wichita Daily Eagle, April 10, 1904.

"Willie's 'Handshaker' Gets Papa into Trouble." The San Francisco Call, April 7, 1907. 
“Wooden Leg as Weapon”. Daily Mail, January 12, 1904.

Daly, Nicholas. Literature, Technology, and Modernity, 1860-2000. Cambridge: Cambridge University Press, 2004.

Daston, Lorraine J. “British Responses to Psycho-Physiology, 1860-1900." Isis 69, no. 2 (1978): 192-208.

Derrida, Jacques. "That Dangerous Supplement." In Of Grammatology, by Jacques Derrida, 141-65. Baltimore: John Hopkins University Press, 1997.

Dickens, Charles. The Pickwick Papers. New York: Hurd and Houghton, 1870.

-. Dombey and Son. London: Penguin, 2002.

- Our Mutual Friend. London: Everyman, 2000.

_. "The Signal Man." All the Year Round 16, no. 400 (1866): 20-25.

Dickie, Simon. "Hilarity and Pitilessness in the Mid-Eighteenth Century: English Jestbook Humor." Eighteenth-Century Studies 37, no. 1 (2003): 1-22.

Dinello, Daniel. Science Fiction Visions of Posthuman Technology. Austin: University of Texas Press, 2005.

Doyle, Arthur Conan. The Sign of Four. Garches: Feedbooks, n.d.

Francis, M. E. “A Rustic Argus.” Longman's Magazine 35, no. 210 (1900): 521-34.

Gavin, Adrienne E. "Dickens, Wegg, and Wooden Legs." Our Mutual Friend: The Scholarly Pages. Accessed June 18, 2018. http://omf.ucsc.edu/london1865/victorian-city/wooden-legs.html.

Gerber, David A., ed. Disabled Veterans in History. Enlarged and revised ed. Ann Arbor: University of Michigan Press, 2012.

Girvan, Ray. "HG Bell: The First Cyborged Leg?" JSBlog-Journal of a Southern Bookreader. Last modified July 6, 2011. http://jsbookreader.blogspot. com/2011/07/hg-bell-first-cyborged-leg.html.

Green, Harvey. Wood: Craft, Culture, History. London: Penguin, 2007.

Hasegawa, Guy R. Mending Broken Soldiers: The Union and Confederate Programs to Supply Artificial Limbs. Carbondale: Southern Illinois University Press, 2012.

Hayes, Kevin J. "Visual Culture and the Word in Edgar Allan Poe's 'The Man of the Crowd." Nineteenth-Century Literature 56, no. 4 (2002): 445-65.

Helmholtz, Hermann von. "On the Conservation of Force." In Nineteenth Century Science: A Selection of Original Texts, edited by A. S Weber, translated by E. Atkinson et al, 280-99. Peterborough: Broadview, 2000.

Henham, Ernest G. “A Human Bundle.” Temple Bar 111, no. 438 (1897): 42-58.

Herschbach, Lisa. "Prosthetic Reconstruction: Making the Industry, Re-Making the Body, Modelling the Nation." History Workshop Journal 44 (1997): 23-57.

Holmes, Oliver Wendell. "The Human Wheel, Its Spokes and Felloes." Sounds from the Atlantic, by Oliver Wendell Holmes, 282-327. Boston: Ticknor and Fields, 1864.

Hood, Thomas. Miss Kilmansegg and her Precious Leg. In Selected Poems of Thomas Hood, edited by John Clubbe, 193-270. Cambridge: Harvard University Press, 1970. 
"How He Turned It with His Wooden Leg". Illustrated Chips 258 (1895): 4-5. [Hudson, Thomas]. "The Cork Leg." [1819-1844] Broadside Ballads Online. Accessed June 21, 2018. http://ballads.bodleian.ox.ac.uk/view/ edition $/ 5413$.

[Hudson, Thomas]. "Cork Leg." In Modern Street Ballads, edited by John Ashton, 153-55. London: Chatto \& Windus, 1888.

Huxley, Thomas Henry. "On the Hypothesis That Animals Are Automata and Its History." Nature 10 (1874): 362-66.

Iguchi, Noboru, dir. The Machine Gun Girl. 2008; New York: Tokyo Shock, 2011. DVD.

Ketabgian, Tamara. The Lives of Machines: The Industrial Imaginary in Victorian Literature and Culture. Ann Arbor: University of Michigan Press, 2011.

Kipling, Rudyard. "Mrs. Bathurst." In Rudyard Kipling, Traffics and Discoveries (New York: Charles Scribner's Sons, 1909), 377-408.

“The Lame Landlord's Story". Temple Bar 20 (1867): 127-34.

La Mettrie, Julien Offray de. L'Homme Machine. Paris: F. Henry, 1865.

Levey, Jay, dir. UHF. 1989; Beverly Hills: MGM, 2002. DVD.

Lewis, Henry Clay. "The Indefatigable Bear Hunter." In Lonisiana Swamp Doctor: The Writings of Henry Clay Lewis, edited by John Q. Anderson, 233-43. Baton Rouge: Louisiana State University Press, 1962.

Lindsay, Christina. "From the Shadows: Users as Designers, Producers, Marketers, Distributors, and Technical Support." In How Users Matter: The Co-Construction of Users and Technology, edited by Nelly Oudshoorn and Trevor Pinch, 29-50. London: Massachusetts Institute of Technology Press, 2003.

Lombroso, Cesare. Criminal Man. Edited and translated by Mary Gibson and Nicole Hahn Rafter. Durham: Duke University Press, 2006.

Marks, George E. Marks' Patent Artificial Limbs with Rubber Hands and Feet. New York: A. A. Marks, 1888.

Marten, James. "Nomads in Blue: Disabled Veterans and Alcohol at the National Home." In Disabled Veterans in History, edited by David A. Gerber, 324-47. Enlarged and revised ed. Ann Arbor: University of Michigan Press, 2012.

Marx, Karl. Capital: A Critical Analysis of Capitalist Production. Translated by Samuel Moore and Edward Aveling. London: Kimble \& Bradford, 1938.

McKean, D. B. “A Wig and a Wooden Leg." Chatterbox 4 (1886): 27.

Melville, Herman. Moby-Dick. London: Penguin, 2012.

Menabrea, L. F. "Sketch of the Analytical Engine Invented by Charles Babbage." Translated with notes by Ada Lovelace. Scientific Memoirs 3 (1843): 666-731. Mihm, Stephen. “'A Limb Which Shall Be Presentable in Polite Society': Prosthetic Technologies in the Nineteenth Century." In Artificial Parts, Practical Lives: Modern Histories of Prosthetics, edited by Katherine Ott, David Serlin, and Stephen Mihm, 282-99. New York: New York University Press, 2002. 
Mitchell, David T., and Sharon L. Snyder. Narrative Prosthesis: Disability and the Dependencies of Discourse. Ann Arbor: University of Michigan Press, 2000.

Morris, Jenny. Pride Against Prejudice: Transforming Attitudes to Disability. London: The Women's Press, 1996.

Murphy, Patricia. "The Fissure King: Parody, Ideology, and the Imperialist Narrative." In The Victorian Comic Spirit: New Perspectives, edited by Jennifer A. Wagner-Lawlor, 23-42. Aldershot: Ashgate, 2000.

"Nineteenth- and Twentieth-Century Prostheses". The College of Optometrists. Accessed June 20, 2018. https://www.college-optometrists.org/the-college/ museum/online-exhibitions/virtual-artificial-eyes-gallery/19th-and-20thcentury-prostheses.html.

Norden, Martin F. The Cinema of Isolation: A History of Physical Disability in the Movies. New Brunswick: Rutgers University Press, 1994.

"New Use for a Wooden Leg”. Nottinghamshire Guardian, June 17, 1899.

O'Connor, Erin. Raw Material: Producing Pathology in Victorian Culture. Durham: Duke University Press, 2000.

Otis, Laura. Networking: Communicating with Bodies and Machines in the Nineteenth Century. Ann Arbor: University of Michigan Press, 2001.

Ott, Katherine. "The Sum of Its Parts: An Introduction to Modern Prosthetics." In Artificial Parts, Practical Lives: Modern Histories of Prosthetics, edited by Katherine Ott, David Serlin, and Stephen Mihm, 1-44. New York: New York University Press, 2002.

- "Hard Wear and Soft Tissue: Craft and Commerce in Artificial Eyes." In Artificial Parts, Practical Lives: Modern Histories of Prosthetics, edited by Katherine Ott, David Serlin, and Stephen Mihm, 147-70. New York: New York University Press, 2002.

Oudshoorn, Nelly, and Trevor Pinch, eds. How Users Matter: The Co-Construction of Users and Technology. London: Massachusetts Institute of Technology Press, 2003.

Packham, Catherine. Eighteenth-Century Vitalism: Bodies, Culture, Politics. Basingstoke: Palgrave Macmillan, 2012.

Park, Nick. Wallace and Gromit: The Wrong Trousers. BBC, 1993.

[Parker, Frances], the Countess of Morley. The Flying Burgermaster: A Legend of the Black Forest. n.p.: F. Morley, 1832.

"Peg-Legged Bob". All the Year Round 11, no. 280 (1874): 563-68.

Poe, Edgar Allan. "The Man That Was Used Up: A Tale of the Late Bugaboo and Kickapoo Campaign." In The Works of the Late Edgar Allan Poe, by Edgar Allan Poe, vol. 4, 315-25. New York: Blakeman \& Mason, 1859.

Plunkett, John, Ana Parejo Vadillo, Regenia Gagnier, Angelique Richardson, Rick Rylance, and Paul Young, eds. Victorian Literature: A Sourcebook. Basingstoke: Palgrave Macmillan, 2011.

Proyas, Alex, dir. I, Robot. 2004; Walt Disney Studios HE, 2004. DVD. 
Rabinbach, Anson. The Human Motor: Energy, Fatigue, and the Origins of Modernity. Berkeley: University of California Press, 1990.

Raimi, Sami, dir. Evil Dead II. 1987; Issy-les-Moulineaux: Studiocanal, 2019. DVD.

Rodriguez, Robert, dir. Planet Terror. 2007; Toronto: Entertainment One, 2008. DVD.

“A Romance of War". Kind Words, May 1, 1872: 145.

Rylance, Rick. Victorian Psychology and British Culture: 1850-1880. Oxford: Oxford University Press, 2000.

Shelley, Mary. Frankenstein, or the Modern Prometheus. London: Norton, 1996.

Shuttleworth, Sally, and Jenny Bourne Taylor, eds. Embodied Selves: An Anthology of Psychological Texts 1830-1890. Oxford: Oxford University Press, 1998.

Siebers, Tobin. "Disability as Masquerade." Literature and Medicine 23, no. 1 (2004): 1-22.

Smith, Roger. Free Will and the Human Sciences in Britain, 1870-1910. London: Pickering \& Chatto, 2013.

Solnit, Rebecca. "The Annihilation of Time and Space." New England Review 24, no. 1 (2003): 5-19.

“The Steam Arm”. In “The Steam Arm': Proto-Steampunk Themes in a Victorian Popular Song," by Kirstie Blair, 204-205. Neo-Victorian Studies 3 (1) 2010: 196-207.

Sussman, Herbert. Victorian Technology: Invention, Innovation, and the Rise of the Machine. Santa Barbara: ABC-CLIO, 2009.

Swade, Doron. "'It will not slice a pineapple': Babbage, Miracles and Machines." In Cultural Babbage: Technology, Time and Invention, edited by Francis Spufford and Jenny Uglow, 34-52. London: Faber and Faber, 1997.

Sweet, Ryan. "'A Human Bundle': The Disaggregated Other at the Fin de Siècle." Victorian Review 40, no. 1 (2014): 14-18.

_. "'Get the Best Article in the Market': Prostheses for Women in NineteenthCentury Literature and Commerce." In Rethinking Modern Histories of Prostheses in Anglo-American Commodity Cultures, 1850-1960, edited by Claire L. Jones, 114-36. Manchester: Manchester University Press, 2017.

Thackeray, William Makepeace. "The Notch on the Ax-a Story a La Mode." Roundabout Papers, by William Makepeace Thackeray, 272-315. Sydney: ReadHowYouWant, 2009.

“The Thief's Arm". In Modern Street Ballads, edited by John Ashton, 150-52. London: Chatto \& Windus, 1888.

Tonkelaar, I. den, H. E. Henkes, and G. K. Van Leersum. "Herman Snellen (1834-1908) and Müller's 'Reform-Auge': A Short History of the Artificial Eye." History of Ophthalmology 4 (1991): 349-54.

"Too Hard Upon My Aunt". All the Year Round 10, no. 242 (1863): 381-84. 
Trollope, Anthony. He Knew He Was Right. Oxford: Oxford University Press, 2008.

Turner, David M., and Alun Withey. "Technologies of the Body: Polite Consumption and the Correction of Deformity in Eighteenth-Century England." History 99, no. 338 (2014): 775-96.

Twain, Mark. Roughing It. London: Penguin, 1988.

Uglow, Jenny. "Introduction: 'Possibility.'” In Cultural Babbage: Technology, Time and Invention, edited by Francis Spufford and Jenny Uglow, 1-23. London: Faber and Faber, 1997.

Ure, Andrew. The Philosophy of Manufactures; or, an Exposition of the Scientific, Moral and Commercial Economy of the Factory System of Great Britain. London: C. Knight, 1835.

"The Use of a Wig-a Hint to the Ladies". The Satirist; or, the Censor of the Times 675 (1845): 90.

Vaughn, Matthew, dir. Kingsman: The Secret Service. 2014; Beverly Hills: 20th Century Fox Home Entertainment, 2015. DVD.

The Walking Dead. AMC, 2010-.

“The Wandering Jew". Chambers's Journal of Popular Literature, Science and Arts 9, no. 458 (1862): 235-36.

Warne, Vanessa. “If You Should Ever Want an Arm': Disability and Dependency in Edgar Allan Poe's 'The Man That Was Used Up.'” Atenea 25, no. 1 (2005): 95-105.

- " “To Invest a Cripple with Peculiar Interest': Artificial Legs and UpperClass Amputees at Mid-Century." Victorian Review 35, no. 2 (2009): 83-100.

Weber, A. S., ed. Nineteenth-Century Science: A Selection of Original Texts. Peterborough: Broadview, 2000.

Wells, H. G. The Time Machine. Oxford: Oxford University Press, 2017.

- The Island of Dr. Moreau. London: Broadview, 2009.

- The Invisible Man. London: Penguin, 2005.

- When the Sleeper Wakes. Project Gutenberg. Last modified September 17, 2016. http://www.gutenberg.org/files/775/775-h/775-h.htm.

- The Food of the Gods and How It Came to Earth. Project Gutenberg. Last modified August 14, 2010. http://www.gutenberg.org/cache/epub/11696/ pgl1696-images.html.

“The Wig Wouldn't Work like the Natural". Illustrated Chips 10, no. 248 (1895): 3 .

Willis, Martin. Mesmerists, Monsters, and Machines: Science Fiction and the Cultures of Science in the Nineteenth Century. Kent: Kent State University Press, 2006.

"Wooden Legs". The Court Magazine and Belle Assemblee 2, no. 3 (1833): 147-51.

"A Wooden Leg That Knows a Thing or Two". Every Week: A Journal of Entertaining Literature 53, no. 1355 (1895): 21. 
Woodforde, John. The Strange Story of False Teeth. London: Routledge and Kegan Paul, 1968.

Youngquist, Paul. Monstrosities: Bodies and British Romanticism. Minneapolis: Minnesota University Press, 2003.

Yuan, David D. "Disfigurement and Reconstruction in Oliver Wendell Holmes's "The Human Wheel, Its Spokes and Felloes."' In The Body and Physical Difference: Discourses of Disability, edited by David T. Mitchell and Sharon L. Snyder, 71-88. Ann Arbor: University of Michigan Press, 1997.

Open Access This chapter is licensed under the terms of the Creative Commons Attribution 4.0 International License (http://creativecommons.org/licenses/ by $/ 4.0 /$ ), which permits use, sharing, adaptation, distribution and reproduction in any medium or format, as long as you give appropriate credit to the original author(s) and the source, provide a link to the Creative Commons licence and indicate if changes were made.

The images or other third party material in this chapter are included in the chapter's Creative Commons licence, unless indicated otherwise in a credit line to the material. If material is not included in the chapter's Creative Commons licence and your intended use is not permitted by statutory regulation or exceeds the permitted use, you will need to obtain permission directly from the copyright holder.

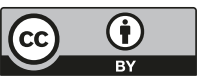

